\title{
OIL PALM ECONOMIC PERFORMANCE IN MALAYSIA AND R\&D PROGRESS IN 2019
}

\author{
GHULAM KADIR AHMAD PARVEEZ*; ELINA HISHAMUDDIN*; SOH KHEANG LOH*; MEILINA \\ ONG-ABDULLAH ${ }^{\star}$; KAMALRUDIN MOHAMED SALLEH*; MOHD NOOR IZUDDIN ZANAL BIDIN*; \\ SHAMALA SUNDRAM*; ZAFARIZAL ALDRIN AZIZUL HASAN* and ZAINAB IDRIS*
}

\begin{abstract}
Despite the uptrend recorded for crude palm oil (CPO) production, yields and exports in general, and an improved overall performance in the last quarter of 2019, the low export price for most part of the year could not steer the industry away from a decline (4\%) in the total export revenue. Sustainable endeavours continue to dominate the palm oil research scene and rightfully so especially when the industry is faced with multi-dimensional challenges. With land expansion being marginal, the importance of good agricultural practice and soil heal th cannot be relegated as a means towards narrowing yield gaps aside from improving the oil palm's genetic potential. The industry's pursuit for circular economy has also led to the adoption of key technologies at every level of the process value chain with zero waste as the ultimate goal. Apart from driving sustainability, the industry has also doubled its efforts in ensuring that palm oil is safe. It is evident that the natural properties of the palm oil make it a healthier and versatile choice for food and its derivatives, respectively. However, its processing methods though need further scrutiny and transformation to allay concerns of its safety. Moving towards a greener and cleaner future, environment-centric policies have helped accelerate the adoption of bio-based materials fuelling palm oil's divergence further into the chemical and energy sectors. To advance the industry's commitment towards sustainability, the Malaysian Sustainable Palm Oil (MSPO) certification was made mandatory embedded as a national policy. With it becoming effective from 1 January 2020, it is anticipated that demand for certified sustainable palm oil (CSPO) will soar and for those who heed the content of the MSPO will come to realise that sustainability lies beyond forests. In general, 2019 was indeed a challenging year for the palm oil industry as a whole, however, this could be deemed a blessing in disguise as the industry has not only risen to the occasion but has proven to be a force to be reckoned with.
\end{abstract}

Keywords: palm oil, sustainability, smallholders, biomass, bioenergy, food and nutrition, oleochemicals, technology, circular economy.

Date received: 6 April 2020; Sent for revision: 7 April 2020; Accepted: 29 May 2020.

\section{INTRODUCTION}

Oil palm, by far is an important commodity crop to Malaysia with export revenue from the crop reaching more than RM 67.12 billion in 2018 (Table 1). There

Malaysian Palm Oil Board, 6 Persiaran Institusi,

Bandar Baru Bangi, 43000 Kajang,

Selangor, Malaysia.

E-mail: parveez@mpob.gov.my was a notable decline of $4.0 \%$ to RM 64.84 billion for 2019 as compared to the 2018 export revenue of RM 67.12 billion, mainly contributed by lower export prices and weaker demand. With approximately 5.9 million hectares of cultivation, the industry is striving harder than ever in addressing issues related to sustainability and its safety put forward by global concern. In spite of these challenges, palm oil is expected to be the key contributor in the edible 
TABLE 1. MALAYSIAN OIL PALM INDUSTRY PERFORMANCE

\begin{tabular}{|c|c|c|c|c|}
\hline & \multirow{2}{*}{2019} & \multirow{2}{*}{2018} & \multicolumn{2}{|c|}{ Difference } \\
\hline & & & Vol./Value & $\%$ \\
\hline Planted area (mil hectares) & 5.90 & 5.85 & 0.05 & 0.9 \\
\hline CPO production (mil tonnes) & 19.86 & 19.52 & 0.34 & 1.8 \\
\hline FFB yield $\left(\mathrm{t} \mathrm{ha}^{-1}\right)$ & 17.19 & 17.16 & 0.03 & 0.2 \\
\hline Oil extraction rate $(\%)$ & 20.21 & 19.95 & 0.26 & 1.3 \\
\hline Palm oil exports (mil tonnes) & 16.88 & 15.36 & 1.52 & 9.9 \\
\hline Palm oil imports (mil tonnes) & 0.98 & 0.84 & 0.14 & 16.1 \\
\hline Closing stocks (mil tonnes) & 2.01 & 3.22 & $(1.21)$ & $(37.6)$ \\
\hline $\mathrm{CPO}$ price $\left(\mathrm{RM} \mathrm{t}^{-1}\right)$ & 2.08 & 2.23 & $(0.15)$ & $(6.9)$ \\
\hline Export revenue (RM billion) & 64.84 & 67.52 & $(2.68)$ & $(4.0)$ \\
\hline
\end{tabular}

Note: CPO - crude palm oil, FFB - fresh fruit bunch, mil - million. Source: MPOB (2020).

oils and fats (World Economic Forum, 2018). Apart from the significant contribution in the edible food and fats along with other industrial processes, the versatile crop is also seen to be playing an important role as the feedstock for biofuels (NgandoEbongue et al., 2012). Celebrating its centennial introduction to Malaysia in 2017, the crop received significant physiological transformation through aggressive systematic breeding and tissue culture developments. The crop produces 10 times higher oil per hectare than any other leading vegetable oil crops with a productive life-span exceeding 20 years. As a perennial crop, oil palm stands tall against all other oilseed crops. Today, with the rapid expansion of cultivation in South-east Asia, Malaysia and Indonesia are the leading producers of palm oil supplying more than $80 \%$ of the global production and continue to dominate the international trade (European Palm Oil Alliance, 2016).

The year 2019 has been fairly a mixture of both positive and negative criticism distressing the overall performance of oil palm industry in the country. Sustainable agriculture has created tremendous pressure on the industry to adhere and stay competitive globally. This was largely sparked by the lack of suitable agriculture land, whereby intensive conversions of non-arable land were taking place in the past few decades, provoking international scrutiny with issues related to sustainability and environment. In order to stay resilient, sustainability developments and environmental issues in agriculture sector are pivotal in the execution and far-reaching undeniably beyond the oil palm. This review article attempts to provide an overview performance of the oil palm industry for the year 2019 whilst critically reviewing the research advances published in the field of research and development (R\&D) that took place for the year 2019. The research advances will first highlight the progress made in the upstream, midstream and downstream across the local value chain before moving into the progress made in the
R\&D worldwide. The article will discuss areas of grave concerns to the industry in order to remain resilient and competitive, areas of improvement whilst identifying transformational and innovative technologies for implementation. Finally, the article will be discussing future directions driving the industry for essential and continued growth.

\section{PERFORMANCE OF THE MALAYSIAN OIL PALM INDUSTRY}

The Malaysian oil palm industry experienced an enhanced performance in 2019 as compared to that of in 2018 where significant achievements have been attained in exports, palm oil stocks and prices. All in all, crude palm oil (CPO) production, exports and imports of palm oil recorded an increase while palm oil stocks, CPO prices and total export earnings of oil palm products declined. Despite the fact that the average CPO price was lower in 2019, the notable export performance, coupled with lower palm oil stocks have driven CPO prices to move on an upward trend, especially towards the last quarter of 2019.

The summary of the Malaysian palm oil industry performance of 2019 vis-à-vis 2018 is as shown in Table 1. Oil palm planted area in 2019 reached 5.90 million hectares, a marginal increase of $0.9 \%$ as against 5.85 million hectares recorded in the previous year due to the increase of newplanted areas mainly in Peninsular Malaysia. CPO production in 2019 recorded a marginal increase of $1.8 \%$, to 19.86 million tonnes as against 19.52 million tonnes in 2018, attributable to improved fresh fruit bunches (FFB) yield and oil extraction rate (OER). Average FFB yield for 2019 improved by $0.2 \%$ to $17.19 \mathrm{t} \mathrm{ha}^{-1}$ while average OER improves by $1.3 \%$ to $20.21 \%$. Strong demand from importing countries, especially India, China and the European Union (EU) has boosted exports of palm oil by $9.9 \%$ to 16.88 million tonnes as compared to 15.36 million tonnes 
in the previous year. Meanwhile, lower export prices of palm oil and other oil palm products took a toll on export revenue.

\section{Planted Area}

Sarawak remained as the largest oil palm planted state with 1.59 million hectares or $26.9 \%$ of the total Malaysian oil palm planted area, followed by Sabah with 1.54 million hectares or $26.1 \%$ (Table 2). Oil palm planted area in Peninsular Malaysia amounted to 2.77 million hectares or $46.9 \%$. Total oil palm matured area accounted for 5.22 million hectares or $88.5 \%$ of the total oil palm planted area in 2019 (Table 3). Sarawak, with 1.42 million hectares of the mature area, represented the largest percentage, covering $89.3 \%$ of total oil palm planted area in the state. Meanwhile, Peninsular Malaysia and Sabah recorded total mature area of 2.44 million hectares and 1.35 million hectares or $88.1 \%$ and $87.7 \%$ of

TABLE 2. MALAYSIAN OIL PALM PLANTED AREA (million hectares)

\begin{tabular}{lcccc}
\hline & 2019 & 2018 & \multicolumn{2}{c}{ Difference } \\
\cline { 4 - 5 } & & & Vol. & $\%$ \\
\hline Peninsular Malaysia & 2.77 & 2.73 & 0.04 & 1.5 \\
Sabah & 1.54 & 1.55 & $(0.01)$ & $(0.6)$ \\
Sarawak & 1.59 & 1.57 & 0.02 & 1.3 \\
\hline
\end{tabular}

Source: MPOB (2020).

TABLE 3. MALAYSIAN MATURE OIL PALM AREA, 2019 (million hectares)

\begin{tabular}{|c|c|c|c|}
\hline & \multirow[b]{2}{*}{$\begin{array}{c}\text { Planted } \\
\text { area }\end{array}$} & \multicolumn{2}{|c|}{ Mature area } \\
\hline & & $\begin{array}{l}\text { million } \\
\text { hectares }\end{array}$ & $\%$ \\
\hline Peninsular Malaysia & 2.77 & 2.44 & 88.1 \\
\hline Sabah & 1.54 & 1.35 & 87.7 \\
\hline Sarawak & 1.59 & 1.42 & 89.3 \\
\hline Malaysia & 5.90 & 5.22 & 88.5 \\
\hline
\end{tabular}

Source: MPOB (2020). total oil palm planted area in the state/region, respectively (MPOB, 2020). In terms of ownership, private estates accounted for 3.61 million hectares or $61.1 \%$ of the total planted area (Table 4). This was followed by independent smallholders with 0.99 million hectares or $16.7 \%$ and the Federal Land Development Authority (Felda) with 0.72 million hectares or $12.3 \%$. In comparison with that of 2018, oil palm planted area under all category of ownership recorded an increase in 2019 except for state schemes/government agencies which was down by 11421 ha. In terms of share of planted area, the share of independent smallholders has slightly declined in 2019 by $0.1 \%$ point due to its lowest planted area growth.

\section{Status of Mills and Plants}

In 2019, there were a total of 452 palm oil mills in operation in Malaysia with a total processing capacity of 112.91 million tonnes of FFB per year (Table 5). Of these, 241 palm oil mills were located in Peninsular Malaysia with a total processing capacity of 56.57 million tonnes per year. Meanwhile, Sabah and Sarawak have 130 and 81 mills in operation with a total processing capacity of 33.74 million tonnes and 22.60 million tonnes per year, respectively. The year 2019 also recorded higher milling capacity utilisation rate by $0.3 \%$ to $87.16 \%$ compared to $86.91 \%$ the previous year due to higher FFB processed (MPOB, 2020).

Meanwhile, a total of 51 palm oil refineries were in operation in 2019 with a total processing capacity of 26.63 million tonnes of $\mathrm{CPO}$ and crude palm kernel oil (CPKO) per year. There were 34 refineries or $57.6 \%$ of total refineries located in Peninsular Malaysia with a total processing capacity of 15.33 million tonnes per year. Sabah and Sarawak recorded 10 and seven refineries with total processing capacity of 7.88 million tonnes and 3.43 million tonnes per year, respectively. The refining capacity utilisation rate for 2019 increased by $8.1 \%$ to $72.12 \%$ from $66.72 \%$ the previous year (MPOB, 2020).

TABLE 4. DISTRIBUTION OF OIL PALM PLANTED AREA BY OWNERSHIP IN MALAYSIA

\begin{tabular}{|c|c|c|c|c|}
\hline & \multicolumn{2}{|l|}{2019} & \multicolumn{2}{|l|}{2018} \\
\hline & million hectares & $\%$ & million hectares & $\%$ \\
\hline Private estates & 3605436 & 61.1 & 3568525 & 61.0 \\
\hline Independent smallholders & 986331 & 16.7 & 979892 & 16.8 \\
\hline Felda & 723545 & 12.3 & 717512 & 12.3 \\
\hline Felcra & 185005 & 3.1 & 179072 & 3.1 \\
\hline RISDA & 72444 & 1.2 & 65512 & 1.0 \\
\hline State schemes/government agencies & 327396 & 5.5 & 338817 & 5.8 \\
\hline
\end{tabular}

Note: Felda - Federal Land Development Authority.

Felcra - Federal Land Consolidation and Rehabilitation Authority.

RISDA - Rubber Industry Smallholders Development Authority.

Source: MPOB (2020). 
TABLE 5. NUMBER OF PALM OIL MILLS, REFINERIES, PALM KERNEL CRUSHERS, OLEOCHEMICAL PLANTS AND BIODIESEL PLANTS AND THEIR CAPACITIES IN MALAYSIA IN 2019

\begin{tabular}{|c|c|c|}
\hline Facility & No. & $\begin{array}{c}\text { Processing } \\
\text { capacity } \\
\text { (million tonnes } \\
\text { per year) }\end{array}$ \\
\hline \multicolumn{3}{|l|}{ Palm oil mill } \\
\hline Peninsular Malaysia & 241 & 56.57 \\
\hline Sabah & 130 & 33.74 \\
\hline Sarawak & 81 & 22.60 \\
\hline Malaysia & 452 & 112.91 \\
\hline \multicolumn{3}{|l|}{ Palm oil refinery } \\
\hline Peninsular Malaysia & 34 & 15.33 \\
\hline Sabah & 10 & 7.88 \\
\hline Sarawak & 7 & 3.43 \\
\hline Malaysia & 51 & 26.63 \\
\hline \multicolumn{3}{|l|}{ Palm kernel crusher } \\
\hline Peninsular Malaysia & 26 & 4.46 \\
\hline Sabah & 13 & 2.10 \\
\hline Sarawak & 4 & 0.70 \\
\hline Malaysia & 43 & 7.25 \\
\hline \multicolumn{3}{|l|}{ Oleochemical plant } \\
\hline Selangor & 9 & 0.85 \\
\hline Johor & 7 & 0.68 \\
\hline Others & 5 & 1.16 \\
\hline Malaysia & 21 & 2.68 \\
\hline \multicolumn{3}{|l|}{ Biodiesel plant } \\
\hline Selangor & 6 & 0.67 \\
\hline Johor & 6 & 0.85 \\
\hline Others & 7 & 0.72 \\
\hline Malaysia & 19 & 2.23 \\
\hline
\end{tabular}

Source: MPOB (2020).

There were 43 palm kernel crushers in operation in 2019 with a total processing capacity of 7.25 million tonnes of palm kernel per year, of which $60.5 \%$ or 26 palm kernel crushers were located in Peninsular Malaysia with a total processing capacity of 4.46 million tonnes per year. Palm kernel crushers in Sabah and Sarawak were 13 and four with a total processing capacity of 2.10 million tonnes and 0.70 million tonnes per year, respectively. The palm kernel crushing capacity utilisation rate for 2019 increased to $65.47 \%$ from $65.45 \%$ in 2018 (MPOB, 2020).
A total of 21 oleochemical plants and 19 biodiesel plants were in operation in 2019 with processing capacities at 2.68 million tonnes and 2.23 million tonnes per year, respectively. The oleochemical and biodiesel plants were concentrated in Selangor and Johor with nine and seven oleochemical plants and six biodiesel plants were in Selangor and Johor, respectively (MPOB, 2020).

\section{CPO Production}

Performance of $\mathrm{CPO}$ production in the first eight month of 2019 was higher as compared to the corresponding period of 2018 due to higher FFB processed resulting from higher FFB yield in the first eight month of 2019. The normal favourable weather condition has brought back production of the first eight month of 2019 into its normal trajectory after experiencing low $\mathrm{CPO}$ production performance in 2018 due unfavourable weather (Kushairi et al., 2019). However, beginning September 2019, the performance was lower vis-à-vis that of 2018 mainly associated with the lower fertiliser application especially by smallholders in the first half of 2019 due to very low FFB prices (Mistry, 2019; Lang, 2020). The highest CPO production in 2019 was recorded in September at 1.84 million tonnes while the lowest was in December at 1.33 million tonnes. CPO production in Peninsular Malaysia and Sarawak increased by 3.8\% and $1.4 \%$ to 10.58 million tonnes and 4.24 million tonnes, respectively, while CPO production in Sabah declined by $2.0 \%$ to 5.04 million tonnes (Table 6).

FFB yield for 2019 increased marginally by $0.2 \%$ to $17.19 \mathrm{t} \mathrm{ha}^{-1}$ as against $17.16 \mathrm{t} \mathrm{ha}^{-1}$ in 2018 due to better yield performance for the first eight months in 2019 (Table 7). FFB yield for Peninsular Malaysia increased by $2.9 \%$ to $17.95 \mathrm{t} \mathrm{ha}^{-1}$ in 2019 compensated for the FFB yield decline in both Sabah and Sarawak. Sabah's FFB yield registered a decline of $2.8 \%$ to $17.66 \mathrm{tha}^{-1}$ from $18.16 \mathrm{tha}^{-1}$, while that of Sarawak was lower by $1.1 \%$ to $15.57 \mathrm{t} \mathrm{ha}^{-1}$ from 15.74 t ha ${ }^{-1}$ in 2018.

OER in 2019 increased by $1.3 \%$ to $20.21 \%$ as compared to $19.95 \%$ recorded in 2018 (Table 8). This was mainly due to better quality FFB processed by palm oil mills. On a quarterly basis, OER for the first quarter of 2019 recorded higher performance as against the corresponding period of 2018, while

TABLE 6. MALAYSIAN CRUDE PALM OIL (CPO) PRODUCTION (million tonnes)

\begin{tabular}{lrrcc}
\hline & \multirow{2}{*}{2019} & \multirow{2}{*}{2018} & \multicolumn{2}{c}{ Difference } \\
\cline { 4 - 5 } & & & Vol. & $\%$ \\
\hline Peninsular Malaysia & 10.58 & 10.20 & 0.38 & 3.8 \\
Sabah & 5.04 & 5.14 & $(0.10)$ & $(2.0)$ \\
Sarawak & 4.24 & 4.18 & 0.06 & 1.4 \\
\hline
\end{tabular}

Source: MPOB (2020). 
OER in the second quarter of 2019 recorded lower performance, year-on-year. OER performance regained its higher momentum in the third and fourth quarters of 2019 except for December where OER recorded lower performance as against that of December 2018.

The highest OER for 2019 was recorded in September at $20.88 \%$ due to higher quality FFB processed as a result of favourable weather conditions. Meanwhile, the lowest OER was recorded in December at $19.71 \%$ due to lower quality FFB processed by mills arising from unfavourable weather condition in all $\mathrm{CPO}$ producing states. All regions recorded higher OER performance in 2019 as compared to that of the previous year. OER in Peninsular Malaysia increased by $1.2 \%$ to $19.93 \%$ while Sabah and Sarawak increased by $1.8 \%$ and $0.9 \%$ to $20.97 \%$ and $20.03 \%$, respectively.

\section{Exports}

Total exports of oil palm products in 2019 stood at 27.98 million tonnes, higher by $10.9 \%$ as against 25.23 million tonnes in 2018 due to increase in exports of palm oil and all other oil palm products
(Table 9). Exports of palm oil increased substantially by $9.9 \%$ to 16.88 million tonnes compared to 15.36 million tonnes in the previous year due to higher export demand especially from major importing countries. Exports of palm kernel oil in 2019 surged by $11.0 \%$ to 1.01 million tonnes from 0.91 million tonnes in 2018 due to the higher demand from China, Turkey and India. Meanwhile, exports of palm-based oleochemicals increased by $7.9 \%$ to 5.19 million tonnes in 2019 from 4.81 million tonnes in 2018 due to stronger demand from the EU, China, Turkey and United Arab Emirates.

Despite the notable export performance, palm oil export revenue declined by $1.6 \%$ to RM 38.03 billion as against RM 38.66 billion in 2018 while palm kernel oil and palm-based oleochemicals were down by $19.1 \%$ and $11.4 \%$ to RM 3.31 billion and RM 16.93 billion, respectively.

Malaysian palm oil exports in 2019 were destined largely to traditional markets. India with the intake in 2019 amounted to 4.41 million tonnes represented $23.9 \%$ of total Malaysian palm oil exports (Table 10). This was then followed by China at 2.49 million tonnes $(13.5 \%)$, the EU at 2.09 million tonnes $(11.3 \%)$ and Pakistan at 1.09 million tonnes

TABLE 7. MALAYSIAN FRESH FRUIT BUNCH (FFB) PRODUCTIVITY (t ha-1)

\begin{tabular}{lcccc}
\hline & \multirow{2}{*}{$\mathbf{2 0 1 9}$} & \multirow{2}{*}{$\mathbf{2 0 1 8}$} & \multicolumn{2}{c}{ Difference } \\
\cline { 4 - 5 } & & & Vol. & $\%$ \\
\hline Peninsular Malaysia & 17.95 & 17.44 & 0.51 & 2.9 \\
Sabah & 17.66 & 18.16 & $(0.50)$ & $(2.8)$ \\
Sarawak & 15.56 & 15.74 & $(0.18)$ & $(1.1)$ \\
\hline Malaysia & 17.19 & 17.16 & 0.03 & 0.2 \\
\hline
\end{tabular}

Source: MPOB (2020).

TABLE 8. MALAYSIAN OIL EXTRACTION RATE (OER) (\%)

\begin{tabular}{lllll}
\hline & 2019 & 2018 & \multicolumn{2}{c}{ Difference } \\
\cline { 3 - 5 } & & & Vol. & $\%$ \\
\hline Peninsular Malaysia & 19.93 & 19.69 & 0.24 & 1.2 \\
Sabah & 20.97 & 20.60 & 0.37 & 1.8 \\
Sarawak & 20.03 & 19.85 & 0.18 & 0.9 \\
\hline Malaysia & 20.21 & 19.95 & 0.26 & 1.3 \\
\hline
\end{tabular}

Source: MPOB (2020).

TABLE 9. MALAYSIAN EXPORTS OF PALM OIL AND OIL PALM PRODUCTS

\begin{tabular}{|c|c|c|c|c|c|c|}
\hline & \multicolumn{2}{|c|}{ Vol. (million tonnes) } & \multicolumn{4}{|c|}{ Value (RM billion) } \\
\hline & 2019 & 2018 & $\begin{array}{c}\text { Difference } \\
(\%)\end{array}$ & 2019 & 2018 & $\begin{array}{c}\text { Difference } \\
(\%)\end{array}$ \\
\hline Palm oil & 16.88 & 15.36 & 9.9 & 38.03 & 38.66 & (1.6) \\
\hline Palm kernel oil & 1.01 & 0.91 & 11.0 & 3.31 & 4.09 & $(19.1)$ \\
\hline Palm-based oleochemicals & 5.19 & 4.81 & 7.9 & 16.93 & 19.11 & $(11.4)$ \\
\hline Other palm-based products & 2.43 & 1.75 & 38.9 & 5.57 & 4.52 & 23.2 \\
\hline Palm kernel cake & 2.48 & 2.40 & 3.3 & 1.01 & 1.13 & $(10.6)$ \\
\hline Total & 27.98 & 25.23 & 10.9 & 64.84 & 67.52 & $(4.0)$ \\
\hline
\end{tabular}

Source: MPOB (2020). 
TABLE 10. MALAYSIAN PALM OIL EXPORTS TO MAJOR DESTINATIONS $(t)$

\begin{tabular}{lcccc}
\hline & 2019 & \multirow{2}{*}{2018} & \multicolumn{2}{c}{ Difference } \\
\cline { 4 - 5 } & & 2514008 & 1895503 & $\mathbf{( \% )}$ \\
\hline India & 4409511 & 1859748 & 630755 & 75.4 \\
China & 2490503 & 1911800 & 181893 & 9.9 \\
European Union & 2093693 & 1161278 & $(75732)$ & $(6.5)$ \\
Pakistan & 1085546 & 631887 & 77375 & 12.2 \\
Turkey & 709262 & 689290 & $(60204)$ & $(8.7)$ \\
Philippines & 629086 & 461567 & 133698 & 29.0 \\
Vietnam & 595265 & & & \\
\hline
\end{tabular}

Source: MPOB (2020).

(5.9\%). Other major markets included Turkey (3.8\%), the Philippines $(3.4 \%)$ and Vietnam $(3.2 \%)$. These top seven traditional markets accounted for 12.01 million tonnes or $65.0 \%$ of total Malaysian palm oil exports in 2019.

India strengthened its position as the largest Malaysian palm oil export market with a significant increase of palm oil uptake in 2019 by $75.4 \%$. The new India import duty under the Malaysia-India Comprehensive Economic Cooperation Agreement (MICECA) effective on 1 January 2019 gave advantage to Malaysian palm oil, especially refined, bleached and deodourised (RBD) palm olein (at $45 \%$ import duty) as compared to that of Indonesian palm oil (at 50\% via ASEAN-India FTA).

Exports of Malaysian palm oil to China increased by $33.9 \%$ was attributed to lower imports of soyabean for crushing by $0.6 \%$ to 87.50 million tonnes in 2019 as against 88.03 million tonnes in 2018 due to lower domestic demand for meal arising from the African swine fever and trade dispute with USA.

Malaysian palm oil exports to the EU rose by 9.5\% to 2.09 million tonnes from 1.91 million tonnes in 2018. This was due to low imports of palm oil from Indonesia by $13.2 \%$ to 2.78 million tonnes during January-October 2019 and higher usage of palm oil as biodiesel feedstock due to insufficient supply of domestic rapeseed oil.

Pakistan maintained its position as the fourth largest export market for Malaysian palm oil since 2016, with an uptake of 1.09 million tonnes in 2019. Exports of palm oil to Pakistan declined by 6.5\% from 1.16 million tonnes in 2018 due to higher imports of soyabean from Brazil for crushing by
$21.0 \%$ to $779000 \mathrm{t}$ during January-November 2019 from $644000 \mathrm{t}$ in January-November 2018.

Meanwhile in Turkey, palm oil exports rose by $12.2 \%$ to 0.71 million tonnes due to lower imports of palm oil from Indonesia by $4.6 \%$ to $208000 \mathrm{t}$ during January-October 2019 as against $218000 \mathrm{t}$ during the same period in 2018.

Exports of Malaysian palm oil to the Philippines declined by $8.7 \%$ to 0.63 million tonnes in 2019 attributed to ample supply of domestic coconut oil for consumption arising from higher production of coconut oil by $3.4 \%$ to 1.15 million tonnes in 2019 from 1.11 million tonnes in 2018.

\section{Imports}

Palm oil represented $74.7 \%$ of total Malaysian imports of oil palm products for 2019, followed by palm kernel oil (PKO) (19.8\%) and palm kernel $(5.5 \%)$ (Table 11). Malaysia imported 1.31 million tonnes of oil palm products in 2019, an increase of $12.6 \%$ compared to 1.16 million tonnes in 2018 . Imports of palm oil rose by $16.1 \%$ to $977131 \mathrm{t}$ from $841452 \mathrm{t}$ in 2018. The increase was partially to fulfil palm oil contract obligation based on either Malaysia or Indonesia delivery and to supplement lower production growth of palm oil in 2019 to cater for higher demand from local processing sector.

\section{Closing Stocks}

Palm oil closing stocks in December 2019 was lower by $37.6 \%$ to 2.01 million tonnes vis-à-vis 3.22 million tonnes recorded in December 2018 (Table 12). The lower closing stocks was mainly due to higher

TABLE 11. MALAYSIAN IMPORTS OF OIL PALM PRODUCTS (t)

\begin{tabular}{lrrrc}
\hline & \multirow{2}{*}{2019} & \multirow{2}{*}{$\mathbf{2 0 1 8}$} & \multicolumn{2}{c}{ Difference } \\
\cline { 4 - 5 } & & & \multicolumn{1}{c}{ Vol. } & $\%$ \\
\hline Palm oil & 977131 & 841452 & 135679 & 16.1 \\
Palm kernel oil & 258925 & 241026 & 17899 & 7.4 \\
Palm kernel & 71994 & 79298 & $(7304)$ & $(9.2)$ \\
\hline Total & 1308050 & 1161776 & 146273 & 12.6 \\
\hline
\end{tabular}

Sources: MPOB (2020). 
palm oil exports. All regions, namely Peninsular Malaysia, Sabah and Sarawak recorded decline in palm oil stocks of $42.5 \%, 33.7 \%$ and $28.0 \%$ to 1.00 million tonnes, 0.65 million tonnes and 0.36 million tonnes, respectively.

\section{Price}

In domestic market, all oil palm products were traded lower in 2019 as against 2018. CPO price was lower by $6.9 \%$ or RM $153.50 \mathrm{t}^{-1}$ to RM $2079 \mathrm{t}^{-1}$ compared to RM $2232.50 \mathrm{t}^{-1}$ in 2018 (Table 13). The highest traded CPO price for 2019 was in December at RM $2813 \mathrm{t}^{-1}$, while the lowest was in July at RM $1879 \mathrm{t}^{-1}$. Although CPO price was lower in 2019, the price was on an upward trend, especially towards the last quarter of 2019. The lower CPO price during the year was mainly due to weaker soyabean oil and Brent crude oil prices in the world market. Prices of processed palm oil products were also lower in 2019. RBD palm oil was traded lower by RM 52 or $2.3 \%$ to RM $2245.50 t^{-1}$, RBD palm olein price was lower by RM 92 or $4.0 \%$ to RM 2236.50 $\mathrm{t}^{-1}, \mathrm{RBD}$ palm stearin price was lower by RM 63 or $2.8 \%$ to RM $2169 \mathrm{t}^{-1}$ and palm fatty acid distillate (PFAD) price was lower by RM 115 or $6.0 \%$ to RM $1807 \mathrm{t}^{-1}$.

The average price of palm kernel in 2019 declined by RM $613.50 \mathrm{t}^{-1}$ or $33.6 \%$ to RM $1214 \mathrm{t}^{-1}$ compared to RM $1827.50 \mathrm{t}^{-1}$ in 2018. The lower palm kernel price was mainly due to the lower domestic price of CPKO. The CPKO price in 2019 declined by RM $1108 \mathrm{t}^{-1}$ or $29.7 \%$ to RM $2626.50 \mathrm{t}^{-1}$ from RM $3734.50 \mathrm{t}^{-1}$ in 2018. The lower CPKO prices in 2019 were in tandem with the weaker world PKO prices, which was lower by $27.9 \%$ to USD $668 \mathrm{t}^{-1}$. Prices of coconut oil were lower by $26.3 \%$ to USD $738 \mathrm{t}^{-1}$ in 2019.

The average FFB price at $1 \%$ OER was lower by $10.9 \%$ at RM 21.17 in 2019 as against RM 23.75 in 2018 , in tandem with the lower prices of CPO and palm kernel. Based on national OER, the average FFB price in 2019 was equivalent to RM $422 \mathrm{t}^{-1}$ as against RM $468 \mathrm{t}^{-1}$ in 2018.

\section{R\&D FOCUS AREAS IN 2019}

\section{Sustainability Driven Advances in Upstream}

The lack of arable land for agriculture expansion to meet the demand of global food security has led to the rapid expansion of less suitable land. Malaysia and Indonesia through private corporations, stateowned companies and smallholders supplying $85 \%$ of the global palm oil (Purnomo et al., 2020) has become a contentious ground for sustainability development and environmental pollution. The year 2019 has witnessed an increase in research and publication related to the detrimental effects of peatland conversion, purpose of conversion and how international policies are capable of reducing the conversion. Peatland conversion using drainage has been identified as the main source of greenhouse

TABLE 12. MALAYSIAN PALM OIL CLOSING STOCKS (million tonnes)

\begin{tabular}{lcccc}
\hline & $\begin{array}{c}\text { December } \\
\mathbf{2 0 1 9}\end{array}$ & $\begin{array}{c}\text { December } \\
\mathbf{2 0 1 8}\end{array}$ & \multicolumn{2}{c}{ Difference } \\
\cline { 3 - 4 } & & 1.74 & $(0.74)$ & $\%$ \\
\hline Peninsular Malaysia & 1.00 & 0.98 & $(0.33)$ & $(42.5)$ \\
Sabah & 0.65 & 0.50 & $(0.14)$ & $(28.0)$ \\
Sarawak & 0.36 & & & Vol. \\
\hline
\end{tabular}

Source: MPOB (2020).

TABLE 13. MALAYSIAN PRICES OF OIL PALM PRODUCTS (RM t-1)

\begin{tabular}{lrrrr}
\hline & 2019 & 2018 & \multicolumn{2}{c}{ Difference } \\
\cline { 3 - 4 } & & & RM t $^{-1}$ & $\%$ \\
CPO & 2079.00 & 2232.50 & $(153.50)$ & $(6.9)$ \\
RBD palm oil & 2245.50 & 2297.50 & $(52.00)$ & $(2.3)$ \\
RBD palm olein & 2236.50 & 2328.50 & $(92.00)$ & $(4.0)$ \\
RBD palm stearin & 2169.00 & 2232.00 & $(63.00)$ & $(2.8)$ \\
PFAD & 1807.00 & 1922.00 & $(115.00)$ & $(6.0)$ \\
Palm kernel & 1214.00 & 1827.50 & $(613.50)$ & $(33.6)$ \\
CPKO & 2626.50 & 3734.50 & $(1180.00)$ & $(29.7)$ \\
FFB at $1 \%$ OER & 21.17 & 23.75 & $(2.58)$ & $(10.9)$ \\
\hline
\end{tabular}

Note: CPO - crude palm oil, RBD - refined, bleached and deodourised, PFAD - palm fatty acid distillate, CPKO - crude palm kernel oil, FFB - fresh fruit bunches, OER - oil extraction rate. Source: MPOB (2020). 
gas emissions (GHG), habitat and biodiversity losses (Anamulai et al., 2019; Cooper et al., 2020; Rulli et al., 2019; Shevade and Loboda, 2019). Drainage in peatlands increases oxygen levels in soil, which in turn escalades decomposition resulting in greater respiration triggering GHG emission. Hence for obvious reason, GHG emission has been the predominant indicator for all studies that have subjected peatland conversion and its management system. Manning et al. (2019) found that the surface microforms in the field had varying GHG emissions whereby greatest fluxes were recorded next to the palms and drainage ditches. In another study, different peatland management systems were analysed and recommended paludiculture as a were potential system (Middelberg et al., 2019). Nonetheless, the system requires additional research especially on technical difficulty (undrainable cycle, intercropping possibilities, yield, harvesting method and value chain) before it can be confidently proposed to the industry.

The different categories of peatlands and their microbial compositions play an important role in peat decomposition. This information is fundamental, especially when there is land use change of peatlands for agriculture purpose. Peatlands store a large amount of terrestrial global carbon (C) and severely impact climate change if not carefully managed. A brief review by Lee et al. (2019) critically examines four influences (change in temperature, precipitation, atmospheric composition and fire and haze) in relation to climate change. Peatland conversion clearly alters the microclimate and soil conditions resulting in adverse ecosystem changes. Apart from the reporting of environmental consequences of conversion, it was also recorded that Indonesian smallholders were poorly informed resulting them to be involved in environmentally detrimental and less compliant land conversions (Schoneveld et al., 2019; Afriyanti et al., 2019). It is imperative that peatland conversion should be carried out in the recommended manner with expert consultation in order to reduce the impact. Studies predominantly suggest greater care in the peatland conversion should be undertaken with strong recommendations to reduce anthropogenic activities that are more likely to negatively affect the unique peat swamp forest (PSF) (Parveez et al., 2019; Charters et al., 2019).

Sustainability developments in the oil palm value chain have been one of the primary concerns of the industry and have been an uphill task in meeting the essential sustainability criteria. Mandatory sustainability schemes such as the Malaysian Sustainable Palm Oil (MSPO) have been vigorously implemented to certify oil palm plantations, independent and organised smallholdings, and palm oil processing facilities. Bearing in mind that these certification will achieve greater transparency in the value chain, research has also been in parallel investigating practical sustainable management strategies potential in increasing biodiversity, habitat complexity and ecosystem functions. In Indonesia for instance, the oil palm industry has teamed up with the academia and introduced Biodiversity and Ecosystem Function in Tropical Agriculture (BEFTA) programme to better understand the oil palm ecosystem and assess sustainability strategies in its ecosystem (Luke et al., 2019). The programme highlights four major sustainability components that address the effect of management strategies by measuring environmental conditions, biodiversity and ecosystem functions. These indicators through BEFTA programmes were able to identify significant complexity and variability existing in tropical agriculture, although oil palm plantations are not as highly complex as seen in tropical forest ecosystem (Luke et al., 2019). Apart from this, sustainability in agriculture and various soil and crop management strategies (CSMS) under sustainable environmental were also critically discussed by Shah and Wu (2019).

Soil is a dynamic system occupying one of the most biologically diversified habitats on the planet. It becomes very apparent with increase in food demand and limited land for agriculture, soil health needs to be conserved if not improved. Focusing on soil health and use of fertiliser, Sundram et al. (2019) critically review the overuse of fertiliser in oil palm and propose a balanced integrated fertiliser application whilst addressing future recommendations on soil health by emphasising soil health rejuvenation. Soil biodiversity is projected as one of the key indicators in measuring soil health holistically with fungal and bacterial communities being the key players (Figure 1). Tropical land use change has always been associated with microflora and macrofauna community shift but due to poor knowledge, it is less explored. The year 2019, however, has a few studies addressing biodiversity in soil communities involving macrofauna, bacterial and fungal soil community shift through the tropical land use change and existing plantations (Brinkman et al., 2019; Ashton-Butt et al., 2019; Shamsilawani et al., 2019). The work by Brinkmann et al. (2019) deliberated on the unexpected findings on the rain forest conversion was actually not associated with strong diversity loss but with massive shifts in fungal community composition. The fungal communities showed strong association to the existing plant species and the land use system. A substantial reduction in symbiotrophic fungi and increases in saprotrophic and pathotrophic fungi communities resulting to increased pathogen pressure. On a positive note, Shamsilawani et al. (2019) showed that bacterial community was influenced by $\mathrm{pH}$ changes and again by the land use system which had pineapple as intercrop, bringing in diverse variation of new phyla. 
Beneficial micrroorganisms as biofertilisers

in sustainable oil palm cultivation

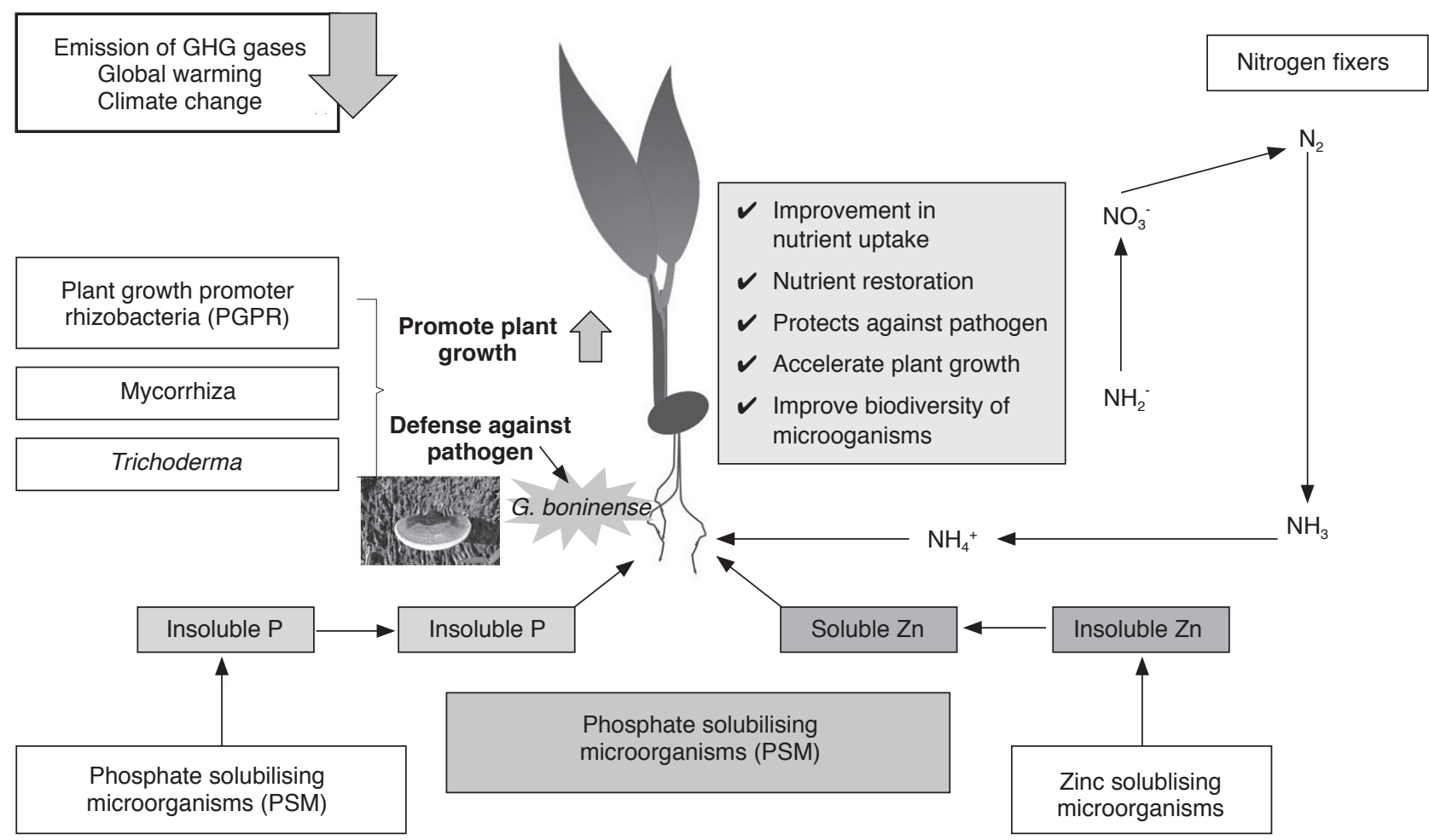

Source: Sundram et al. (2019).

Figure 1. Potential usage of soil microbes as a biofertiliser for sustainable oil palm cultivation.

Every crop has its specific requirements of nutrients and it is almost impossible to acquire substantial amount of nutrients from the soil. External input of fertiliser is inevitable to achieve optimal yield which explains $30 \%$ of the operating cost in the oil palm industry going to fertiliser. The 2019 studies investigated on some aspects of fertiliser use namely; GHG emissions, lipid metabolism, biodiversity and precision agriculture (Rahman et al., 2019; Miranda-Ney et al., 2019; Darras et al., 2019; Dubos et al., 2019). The GHG emission work revealed an interesting yet sustainable approach by concluding that emission $\left(\mathrm{N}_{2} \mathrm{O}\right.$ and $\left.\mathrm{CH}_{4}\right)$ was greater with the use of inorganic fertilisers as opposed to the use of organic fertilisers, and precipitation influences GHG emissions. The finding suggests that nutrient application in the field should be managed appropriately to reduce emission due to the influence of precipitation. Very few articles investigated the influence of potassium (K) fertilisation on fruit oil content and composition of various crosses. With the clear finding that $\mathrm{K}$ availability influences bunch oil content by reducing water content and higher oil proportion in fruit mesocarp of Deli x La Mé but not in Deli x Yangambi suggesting fertiliser management should be customised according to the need of the crosses (Miranda-Ney et al., 2019). Taking into consideration the effect of fertiliser on operating cost and sustainability, there needs to be more studies investigating the influence of fertiliser on palm physiology and environment.

Ideally, plants planted under optimal growth conditions will produce the projected yield, but in reality, the crop is constantly experiencing challenges from numerous attacks by pests and diseases (P\&D). In the case of oil palm, the industry has been managing the $P \& D$ endeavours through the implementation of integrated pest management (IPM) that has been proven to give substantial control. Whilst being mindful that there is an immediate need of an effective control, efforts are increased towards a greener and sustainable control. With the current emphasis on sustainability, the year 2019 saw the increase in publications relating to the biocontrol agent (BCA) Trichoderma with a review highlighting its potentials and its weaknesses by Adnan et al. (2019). MPOB further highlighted its potentials as a plant growth enhancer with the publication by Farah et al. (2019) through in vivo approach apart from its efficacy as BCA was further established by Muniroh et al. (2019). Additionally, innovative approaches using phytol-containing seaweed extracts rich with anti-fungal compounds ameliorated control of Ganoderma. Nonetheless, research still foresees a lesser green approach through publication by Said et al. (2019) which 
identified Pyraclostrobin as a potential fungicide against Ganoderma with significant promotion in plant growth despite being a chemical control.

Whilst bearing in mind that an effective control is required to keep P\&D threats at bay, research for early detection methods is essential towards a successful management and control of P\&D challenges. The terrestrial laser scanning (TLS) is a remote sensing, non-contact, cost-effective, precise technology and user-friendly method was explored and found to be able to detect low-level infection symptom of basal stem rot (BSR) disease in the field (Azuan et al., 2019). Meanwhile, fundamental research by Midot et al. (2019) investigated the diversity and demographic history of Ganoderma boninense from oil palm planted in peat and found that $G$. boninense identified as the causal agent through single nucleotide polymorphism (SNP)-ITS region. The analysis showed one common major G. boninense haplotype distributed throughout Sarawak. This information is important considering the fact that previous publications highlighted the possibility of two Ganoderma species associated with BSR and upper stem rot (USR) in East Malaysia (Rakib et al., 2017). Bearing this in mind, fundamental research requires to be carried out to elucidate the aetiology of the pathogen, which still has a huge knowledge gap in its taxonomy and distribution despite its economic importance.

Aside from addressing indigenous $P \& D$ threats, research was also intensified on exotic diseases that may pose a biosecurity threat. The deadly bud rot disease that causes catastrophic losses to oil palm in the South American countries have Phytophthora palmivora identified as the causal agent. The oomycete is an important indigenous pathogen infecting various annual and perennial crops such as durian, cacao, jackfruit and pepper. Maizatul et al. (2019) found that there was no significant difference via molecular characterisation between Malaysian and Colombian isolates while pathogenicity tests using local isolates on oil palm found no adverse effect on oil palm despite the fact that it was able to infect multiple hosts (Intasit et al., 2019). Whilst those are the efforts of addressing the threat of P. palmivora by local researchers, Colombian researchers have elucidated the mechanism of infection by the pathogen via GFP transformation and detected cell death responses associated with immature oil palm tissues (Ochoa et al., 2019).

Damages by pests in the oil palm cultivation are catastrophic which require early intervention through rigorous control methods, IPM and chemical control. Bagworm for instance is capable of defoliating the leaves to the extent of skeletonising the canopy resulting in significant reduction in growth and yield. Thus, early intervention requires effective tools to assist the control and one such technology reported remote sensing (RS), a satellite technology, was able to relate relative humidity $(\mathrm{RH})$ to predict outbreak with high correlations and accuracy of 93\% (Ruslan et al., 2019). Whilst being a non-invasive technique, the geospatial technique allows early warning and followed by suitable control measures. While bagworm is a pest of oil palm, Rhynchophorus ferrugineus has been causing devastation in the coconut fields along the east coast and there is a great fear that the pest would relocate to oil palm in close proximity. The efficacy of a biopesticide-based control is being investigated through three eugonel compounds and were found to significantly deter feeding in the larvae (Tay et al., 2019). Although the study is still very preliminary and requires a field assessment before it can be proposed to the industry, green controls are always welcomed and the more sustainable approach in management of any pest and should be explored further.

Sustainability in agriculture should not be an option but rather mandatory due to the importance of ecological balance while avoiding depletion of natural resources for future generation. It should be incorporated and emphasised in every value chain in the agriculture sector to preserve the agrobiodiversity. Kamarudin et al. (2019) have addressed some of the sustainable approaches that were employed in the management of bagworms and rhinoceros beetle delivering a holistic management of both pests. It was highlighted that more research on ecosystem services will be able to contribute to a more sustainable and benign control on pest of oil palm.

As oil palm cultivation is labour intensive, automation and mechanisation R\&D are key target in reducing farm operating cost besides others like ecological factors. A system - dynamics modeling of oil palm productivity has shown that gradual transition to automation and mechanisation could save up to $27 \%$ of the oil palm cultivation baseline operating costs (Ibragimov et al., 2019). A spatial planning tool has also been established to integrate the effects of soil, transport, waterways and riparian management for sustainable distribution of oil palm residues in West Malaysia (Truckell et al., 2019). This kind of tool helps in designing suitable mechanisation devices. Device such as vibration isolators is able to reduce the level of hand-arm vibration of the motorised cutter, CANTAS by an average of $49.5 \%$, hence could significantly reduce health risk to oil palm operators (Jelani et al., 2019).

\section{Crop Improvement through Adoption of Technology}

It is interesting to note that in 2019, the oil palm tissue culture research arena is still evidently active with the publication of several articles on this topic. The review by Weckx et al. (2019) emphasises the 
fact that tissue culture has the potential to provide sustainable high yielding planting material as an alternative over hybrid seeds. However, the inefficiencies in the tissue culture process need to be addressed to improve the utilisation of oil palm clones which stands at 2\% (Kushairi et al., 2010). The vegetative propagation method employed for oil palm via indirect somatic embryogenesis was determined based on its natural architecture of having a single meristem. This brought about several difficulties such as low embryogenesis and regeneration rates with risk of somaclonal variation. To mitigate these issues, several key suggestions were provided such as the use of alternative explants (starting material) in particular, immature inflorescences instead of immature leaves (Guedes et al., 2011) as this provides multiple regenerative meristems as opposed to one (Zayed et al., 2016). Propagating through direct somatic embryogenesis was also suggested as it is less susceptible to somaclonal variation (Jayanthi et al., 2011). Early screening of highly embryogenic responsive palms using candidate genes (Le et al., 2010; Ooi et al., 2012; Syariyanto et al., 2018) could ultimately help in improving efficiency through reduction in labour and cost. Aside from genes, proteins such as antioxidants, those involved in cell division as well as ubiquitination could serve as markers for acquisition of embryogenic competency (Ribeiro et al., 2019). The idea of improving the quality of somatic embryos for better regeneration by creating a desiccated environment is an interesting thought worth pursuing (Wecke et al., 2019).

SureSawit ${ }^{\mathrm{TM}} K A R M A$ test used for early detection of mantling (a form of flower abnormality) in the field does help to allay some of the apprehension associated to planting clonal oil palms (OngAbdullah et al., 2016). However, its specificity in discriminating false positives still needs further tweaking. In line with this, a combination of detection techniques may add power to the test (Flusberg et al., 2010). The use of laser capture microdissection (LCM) was introduced to further understand factors involved in mantling of the oil palm (Ooi et al., 2019). This technique enables female and male floral organs to be microscopically isolated and processed separately for specific downstream analyses and hopefully for a more accurate interpretation of the process. One thing that stands out is the decreased expression of the HEAT SHOCK PROTEIN genes amongst the mantled floral organs regardless of the sex of the flower indicating lower stress indicators.

The oil palm cloning system not only enables the production of superior planting materials with high oil yields and other desirable traits, but more importantly it creates the possibility of producing identical copies or uniformed palm stands. Zou et al. (2019) conducted a comparative analysis on triacylglycerol (TAG) between calli and mesocarp which led to the conclusion that their fatty acid content is very similar. This provides an ideal platform for embryogenic cultures to be used as reference to predict fatty acid profiles in the mesocarps of mature fruits.

With the introduction of disruptive approaches and big data support, viability of conventional methods is now in question. The traditional scheme of mass selection for genetic improvement of yields in oil palm has over time evolved to accommodate more efficient schemes such as the modified reciprocal recurrent selection (MRRS) type (Nyouma et al., 2019). The changes adopted include better statistical methods to estimate the genetic value of the selection candidates by replacing the analysis of variance (ANOVA) with best linear unbiased predictor (BLUP) method. The other more recent modification is the incorporation of genomic data. Apparently, the genomic selection (GS) approach is best applied on quantitative traits such as yield (Meuwissen et al., 2001). In a nutshell, GS is in fact a marker-assisted selection (MAS) method combined with specific statistical approaches such as BLUP. This efficiently enables genomic estimated breeding values (GEBV) to be quantified for selection of parents for hybrid crosses. This approach can also be extended for ortet selection. Generally, the main advantage of this new scheme is its ability to shorten breeding cycles (which could take up to 20 years) by eliminating field evaluations in some cycles as well as to increase selection intensity (quantity) which is a limitation with conventional methods (Figure 2). For GS to be practical, Jacob et al. (2017) worked out that the genotyping cost is being offset by a lower phenotyping cost brought about by fewer field evaluations, resulting in the cost per genetic progress unit to be 35\%-65\% lower than conventional selection.

Research on further enriching the oil palm breeding information and genome database to support mining of important traits as well as for marker-assisted breeding continue to dominate publications. Xia et al. (2019a) introduced the use of the single locus amplified fragment sequencing (SLAF-seq) technology to develop high-density single nucleotide polymorphism (SNP) markers. In addition to that, the first microsatellite database (OpSatdb) was established by Kalyana Babu et al. (2019a), which acts as a repository of microsatellite markers. Thus, allows users to retrieve desired markers for future use. In a separate article, Kalyana Babu et al. (2019b) utilised genome wide association studies (GWAS) on individuals from four germplasms namely, Cameroon, Tanzania, Guinea Bisseau and Zambia to assess for height increment. From the five significant quantitative trait loci (QTL), one on chromosome 7 seemed most promising. The QTL was found to be similar to oil palm's B3 domain-containing protein which 
(a)
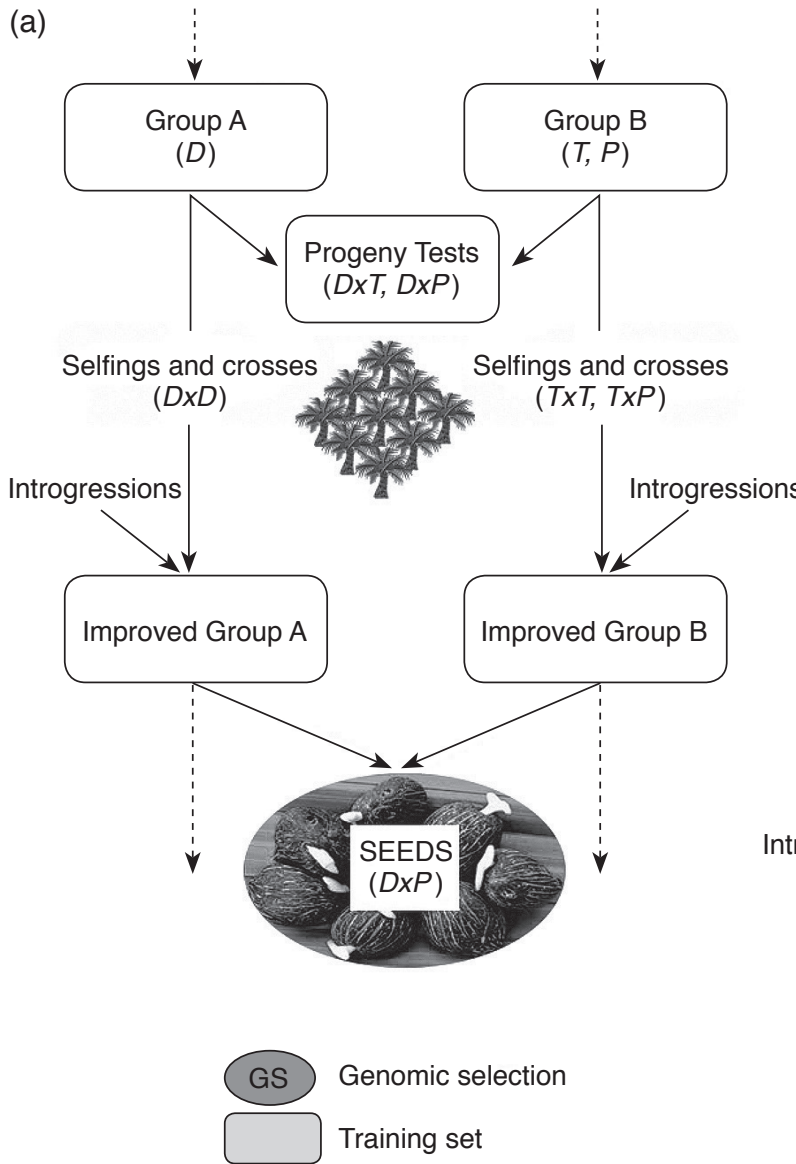

(b)
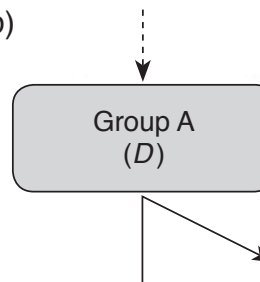

Selfings and crosses Progeny Tests

4

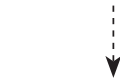
Group B $(T, P)$ $(D \times D)$

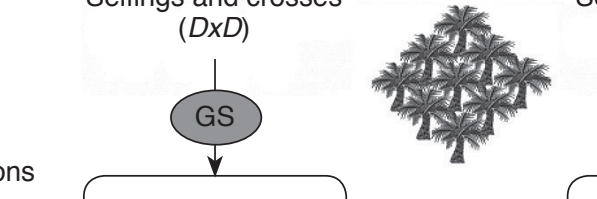
Selfings and crosses (TXT, TXP)

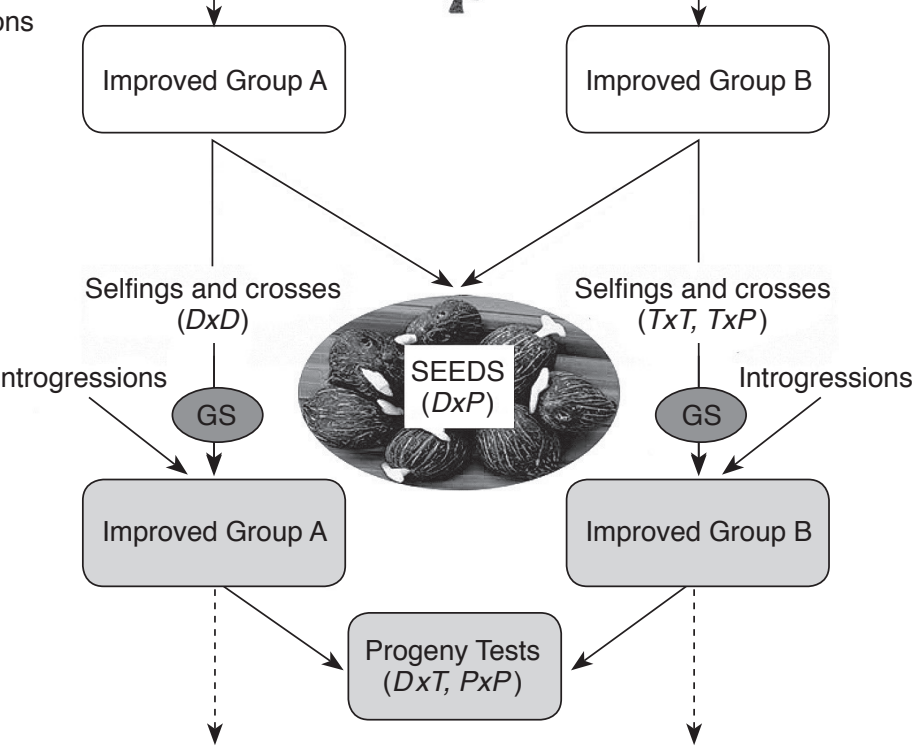

Source: D - dura, T - tenera, P - pisifera, DxP commercial seeds adapted from Nyouma et al. (2019).

Figure 2. (a) The oil palm one cycle modified reciprocal recurrent selection scheme. (b) The proposed genomic modified reciprocal recurrent selection scheme for increased selection intensity in large populations of seedlings (cycles 1 and 2) and shortened breeding cycles (cycle 2) for oil palm.

could bring us closer to the identification of gene(s) involved in stem height increment. As a step towards augmenting downstream research, developing planting materials for this purpose is targeted. Myint et al. (2019) identified families within the Senegal germplasm that possess high kernel content which could indicate a prospective source of lauric acids for the oleochemical industry.

The acquisition of multivariate datasets ('omics' datasets) are increasingly prevalent as they provide a more holistic molecular perspective of biological systems as opposed to conventional methods. Wang et al. (2019) established an integrated omics analysis on phytohormones involved in seed germination. Basically, through this study, abscisic acid (ABA) was found to inhibit germination and heat treatment could break the dormancy by eliminating endogenous ABA. Despite the advantage of an integrated approach, stand-alone 'omics' studies are equally beneficial for data generation. BSR a disease caused by Ganoderma infection is becoming more widespread and serious causing major economic losses to the oil palm industry. In recent study by Ho et al. (2019), leaf transcriptome from infected palms via root inoculation versus control were analysed and differential genes expressed were identified. Salicylic acid- and oxylipin-mediated defence pathways were triggered in infected palms as well as genes encoding for enzymes associated with flavonoids, alkaloids and terpenes while genes involved in photosynthesis were suppressed. This suggests leaves divert their resources for defence at the expense of other biological processes during infection.

Another biotechnological tool that is trending is in the use of microRNA (miRNA) precursors to understand the biological function of the oil palm. These microRNAs, a class of non-coding RNAs, are important in regulating gene expressions (da Silva et al., 2016). Gao et al. (2019) revealed that EgmiR5179, a conserved miRNA, is involved in oil accumulation in the oil palm mesocarp through the down regulation of the NAD Transporter 1 (NDT1) gene. From the aspect of the fatty acid content in palm oil, Xia et al. (2019b) utilised GWAS to identify SNP markers in an attempt to screen for oil palms with distinct palmitic acid content. Their analysis led to the discovery of acyl-ACP thioesterase B genes 
that are involved in fatty acid biosynthesis and associated with the accumulation of high palmitic acid in mesocarp, which can then be subsequently used to breed for low palmitic acid varieties.

Interspecific hybrid (Elaies oleifera $x$ Elaies guineensis) research is gaining importance mainly brought about by economic losses faced by the Latin American countries due to the susceptibility of E. guineensis (Eg) towards bud rot disease. These hybrids leverage the desirable combined characteristics of both species such as high oil production from $\mathrm{Eg}$, while better quality oil as well as resistance to different diseases from E. oleifera (Eo) (Astorkia et al., 2019). In addition, slow trunk growth and the ability to produce parthenocarpic fruits are also traits descending from Eo (Osorio-Guarin et al., 2019). Through GWAS, Osorio-Guarin et al. (2019) revealed five significant genomic regions associated with plant architecture and yield. In the case of Astorkia et al. (2019), seven potential candidate genes targeting production traits, whilst 23 others influenced by quality traits were discovered through association studies based on candidate genes derived from in silico mining using various sources. Collectively this information provides the impetus for further development of MAS breeding for oil palm.

\section{Sustainable Developments for Smallholders}

Despite the noble efforts of the Roundtable on Sustainable Palm Oil (RSPO) in striving to create a more sustainable palm oil industry, its overly restrictive system was deemed impractical for key players such as the smallholders to readily adopt the recommended practices (Corley, 2018; Hutabarat et al., 2019). With this realisation, the MSPO as well as its close ally the Indonesian Sustainable Palm Oil (ISPO), were developed in order to provide equal opportunity to the smallest of farmers to be a part of the more lucrative market of certified sustainable palm oil (CSPO) production.

The MSPO certification, launched in 2013 started off as a voluntary national standard as a means to distinguish 'Malaysian Palm Oil' from palm oil per se. It was subsequently made mandatory with full adoption by the whole industry by 31 December 2019. This bold move is meant to stamp Malaysia's commitment towards sustainability, which includes all sectors even the independent smallholders. This sector, which represents $17 \%$ or 0.99 million hectares from the nation-wide total oil palm planted area of 5.85 million hectares, has continuously contributed significantly to the national oil production (Kushairi et al., 2019). Senawi et al. (2019) stressed that through the mandatory implementation of MSPO, independent smallholders could further enhance the three pillars of sustainability, the environment, social and economy elements. Audit findings have provided positive feedback on the impact of MSPO on practices in smallholdings, where efforts are seen to be channelled towards protecting the environment by reducing the use of chemical contaminants, maintaining riparian zones and protecting wildlife animals. These safe and environ-centric MSPO practices also place certified smallholders in good stead with other stakeholders in the community that may be affected by their operations. In addition, compliance with MSPO requirements on agricultural best practices will further improve yields and thus, enhance the livelihood of the independent smallholders.

In order to meet the current global demand for a more ethical and sustainable farming condition, the management aspect of the agricultural practice needs to substantially change. Livestock integration, perceived to be an innovative biological weed control method for vegetation in oil palm plantations, is also considered an environmental-friendlier alternative. Besides reducing the dependency on chemical herbicides, livestock integration also provides additional food security, ecosystem services, and habitat heterogeneity. This was further supported by the study done by Tohiran et al. (2019a), where growth of understorey vegetation was encouraged through cattle grazing. Data collected from 45 plantations in Peninsular Malaysia showed that plantations implementing cattle integration had an average of $20 \%$ more undergrowth coverage than without. However, the undergrowth height did not impact the management of the estate. Nonetheless, maintaining undergrowth at a reasonable height will ensure that the day-to-day operations in the oil palm plantations are not disrupted.

The other issue at hand is the loss of biodiversity. Oil palm expansion has been commonly linked to biodiversity loss as rainforest is converted into plantation. Introducing sustainable oil palm farming practices to smallholdings could possibly mitigate biodiversity losses and increase agricultural sustainability. The integration of cattle into oil palm plantation not only controls the undergrowth, but also improves the avian biodiversity (Tohiran et al., 2019b). Cattle grazing in oil palm enhanced the composition of farmland bird species in oil palm plantations. Studies conducted found that both oil palm plantations with systematic and nonsystematic cattle grazing had greater avian diversity. Furthermore, the avian insectivores make up the majority of the farmland birds observed.

The influence of human element cannot be taken for granted when dealing with smallholdings. Their attitudes and desires are generally governed by their community's culture. For example, even if smallholders are well informed of commonly followed practices that are unsustainable, it is difficult to bring about change as these practices are strongly imbibed within the smallholding 
communities. This is where extension agents play a significant role. They are expected to provide advice and recommendations befitting the smallholders' communities based on their respective cultures and beliefs. MPOB, through its team of extension agents known as TUNAS (Tunjuk Ajar \& Nasihat Sawit) officers, is on site to provide advisory services as well as to educate smallholders on the advantages of adopting oil palm related technologies for better productivity through sustainable oil palm management. The effectiveness of TUNAS officers in the development of oil palm smallholdings has been well documented by Awang et al. (2016). Currently, aside from conducting extension activities, these officers have been tasked to prepare smallholders in MSPO certification. They are to facilitate and assist the oil palm smallholders towards compliance with the certification requirements (Senawi et al., 2019). Study conducted by Azian et al. (2017) revealed that $66.1 \%$ of the 663 independent oil palm smallholders are aware of sustainable agriculture practices in managing their farms. Evidently, the transfer of knowledge through interaction and communication between smallholders and their respective extension agents have been effective and this have led to better management of their land. Smallholders too tend to rely more on informal programmes to expedite learning which further emphasises the importance of having a good social network within this sector. Based on the study conducted by Sahidan et al. (2019), having good connections or network amongst smallholders within the society seemed to have a positive impact on FFB productivity.

Maximising profits of smallholdings is another element that needs consideration when discussing sustainable oil palm cultivation. One of the ways of achieving this is through the introduction and adoption of new agriculture technologies by smallholders. Besides knowledge on harvesting, effective fertiliser management is another major factor affecting FFB production (Peng et al., 2019). Good fertiliser management will ensure good oil palm growth for optimal bunch production. The study by Peng et al. (2019) pointed out that independent smallholders tend to have poorly managed farms, in terms of fertiliser application and management. The study also found that respondents generally have good knowledge of fertiliser nutrient content as well as their application methods, however they lack the knowledge of recognising nutrient deficiency symptoms in the oil palm. Fertiliser management is considered priority as it makes up $60 \%$ of the total production cost.

Another possible strategy to maximise smallholders' income is through the implementation of crop integration within the oil palm estate. One of the initiatives is to integrate rubber (latex) timber clone (LTC) with oil palm. The feasibility of this initiative was conducted by Khasim and Omar
(2019). The rubber clones, namely the RRIM 2024 and RRIM 2025, grew well under the double avenue oil palm planting system, producing cup lumps and rubber wood log regardless of the oil palm planting densities. However, oil palm FFB production was significantly reduced from as early as year five of harvest and continue to decrease for the next four consecutive years until year nine of harvest. Competition for light and nutrient between LTC rubber trees and oil palm were cited as the major factors contributing to the reduction in oil palm FFB production. It was also reported that yields from LTC would not be able to compensate the losses from FFB yield, therefore integration with LTC was considered a failure.

Governmental support is an important factor to help boost oil palm smallholders' capabilities and productivity in managing their oil palm. More than usual, low productivity of independent smallholders is commonly linked to the cultivation of planting materials that is of low quality or maintaining unproductive mature oil palms in their fields. This is either due to the lack of awareness or due to the financial restriction arising from smallholders' end. Besides having good agriculture practices (GAP), recommended fertiliser application towards achieving higher productivity, it is essential in ensuring that fields are planted with high quality planting materials and unproductive palms in fields are replaced. Acknowledging these shortcomings within the smallholders, the Malaysian government in its $9^{\text {th }}$ Malaysian Plan, introduced assistance scheme to help smallholders replant their fields with high quality planting materials. The scheme was initially introduced in Sabah and Sarawak in 2005 and eventually was also made available for smallholders in Peninsular Malaysia in 2007. Interestingly, after more than 10 years, recipients of the scheme recorded yields ranging from $22.4 \mathrm{t} \mathrm{ha}^{-1}$ to $28.9 \mathrm{t} \mathrm{ha}^{-1}$ which was able to be retrieved from a study conducted by Rahmahwati et al. (2019). In addition, the study also pointed out that factors such as fertilisers, farm size, harvesting and services provided by the MPOB TUNAS officers influenced the production of FFB by the scheme recipients. Besides providing high quality planting materials, the government also introduced the Stimulus Economic Package II Incentive Scheme (PRE2) with the specific objective to assist smallholders in Peninsular Malaysia replace old and unproductive oil palms through this replanting scheme. The replanting scheme grants monetary assistantship of RM $7500 \mathrm{ha}^{-1}$ to cover the cost of replanting that includes land clearing, seedlings, fertilisers, pesticides and herbicides. Again, the impact of the scheme was investigated by Hamid et al. (2019) specifically focusing on the yield and income of the smallholders. The study revealed that the scheme recipients could produce 
an average yield up to $9.28 \mathrm{tha}^{-1}$ of FFB in the first year of harvest, with an estimated yearly income of RM 4344 ha $^{-1}$.

\section{Biomass and Bioenergy Innovations}

Three main R\&D focus areas in midstream palm oil sector are by-products from milling, oil palm biomass, energy and environment. In the palm oil milling process, many by-products are generated; the most abundant are palm oil mill effluent (POME) and empty fruit bunches (EFB). In tackling the disposal issue of these by-products, POME and EFB need to be treated and reused cost-effectively. While selection of feasible technology for POME treatment is crucial in meeting current regulatory compliance, biochemical oxygen demand of $20 \mathrm{mg}^{\text {litre }}{ }^{-1}$, other emission parameters previously not monitored such as colour and odour of POME will soon be enforced (Abdul Hadi et al., 2019; Mohamed Halim and Abd Aziz, 2019). Hence, reducing POME could be the most strategic alternative via evaporation, undiluted clarification or water recycling to conventional POME management gearing towards a zero effluent discharge milling process (Ahmad Farid et al., 2019; Tan and Lim, 2019).

While scrutinising means of POME elimination through an integrated approach in a palm oil mill complex, focus was still on accelerating POME breakdown during anaerobic digestion to enhance biogas/syngas production ( $\mathrm{Ng}$ et al., 2019; Zaied et al., 2019) using some of the high-rate anaerobic reactors and co-digestion aided by solar and chemical oxidation. Millers will soon have an option to either capture biogas for energy use or embark on more innovative methods to promote sustainable palm oil milling for a balanced economic and environmental advantage (Tan and Lim, 2019). The captured biogas, if combusted under a properly controlled fuel mix ratio, could ensure high palm oil mill boiler efficiency and low particulate emissions in meeting the permitted limit as stipulated in the Malaysian Environmental Quality (Clean Air) Regulations, 2014 (Nasrin et al., 2019). Up till end of 2019, 125 biogas plants have been operational in the country which corresponds to $28 \%$ nationwide biogas implementation (Loh et al., 2019a). Other alternative approach is to recover the various palm oil milling by-products fully, particularly the POME for integrated harnessing of biogas, recycled water and organic fertiliser in meeting nexus (foodenergy-water) resources demand and conserving the environment for a circular economy (Loh et al., 2019b).

The year 2019 saw the implementation of mandatory use of B10 (10\% palm biodiesel and 90\% petroleum diesel) in the transportation sector in February (Nursyairah et al., 2019) followed by B7 for industrial sector starting July the same year. A new precise nuclear magnetic resonance spectroscopic technique in monitoring palm biodiesel and its blends was established ( $\mathrm{Ng}$ and Yung, 2019). Due to the food vs. fuel issue, a shift from conventional biodiesel feedstock (vegetable oil) to waste oil such as residual POME oil (Matinja et al., 2019), waste cooking palm oil (Maneechakr and Karnjanakom, 2019) and palm biomass waste (Ahmad et al., 2019a; Intasit et al., 2019) was investigated. Biodiesel production from waste cooking oil catalysed by $\mathrm{CaO}$ like waste chicken eggshell has lesser environment impact than vegetable oil-based feedstock as it does not involve agriculture phase, chemical and additives and complex purification and neutralisation processes during the production phase (Chung et al., 2019).

The oil palm biomass has largely been exploited as potential feedstock for advanced biofuels, biochemical and biomaterials production through either direct use or undergoing physical, thermal, chemical or biological conversion and synthesis. For the latter option, some promising pre-treatment methods have been established using ionic liquids or deep eutectic solvents which facilitate unlocking of the complex lignocellulosic biomass structure (Mahmood et al., 2019; Teh et al., 2019). Many deriving platform chemicals, e.g. succinic acid (Bukhari et al., 2019) and levulinic acid (Tiong et al., 2019) can be used as building blocks coupled with hybrid synthesis to produce a variety of advanced biofuels such as gasoline, diesel, jet fuel and biochemical/ oleochemical. Although several biomaterials are of great interest derived from oil palm biomass, e.g. advanced particleboard (Komariah et al., 2019), biocomposite (Ramle et al., 2019), biosorbent (Lau et al., 2019) and engineered carbon material or activated biochar (Kong et al., 2019; Zhang et al., 2019), the other emerging field lies in structural modification of isolated lignin having an improved antioxidant activity (De Menezes Nogueira et al., 2019; Abd Latif et al., 2019). In years to come, a biorefinery (Figure 3) could potentially be established integrating all potential existing bioconversion routes for multiple production not only to improve the economics but also the sustainability of the industry (Ahmad et al., 2019a, b).

The future concept of biorefinery needs to consider upscaling all of the industrial facilities in an integrated manner combining the $R \& D$ efforts and strengthening policies for the intended purpose to realise the circular palm oil economy (Loh et al., 2019b; Severo et al., 2019). In this regards, various biomass value chain assessment modellings have been developed to ensure palm oil supply chain (including palm oil and oil palm biomass) is sustainable for commercial exploitation (Zahraee et al., 2019; Rubinsin et al., 2020). In Brazil, Munasinghe et al. (2019) assessed the economic, environmental and social sustainability of CPO production based 


\section{OIL PALM INDUSTRY INTEGRATED PROCESSING COMPLEX}

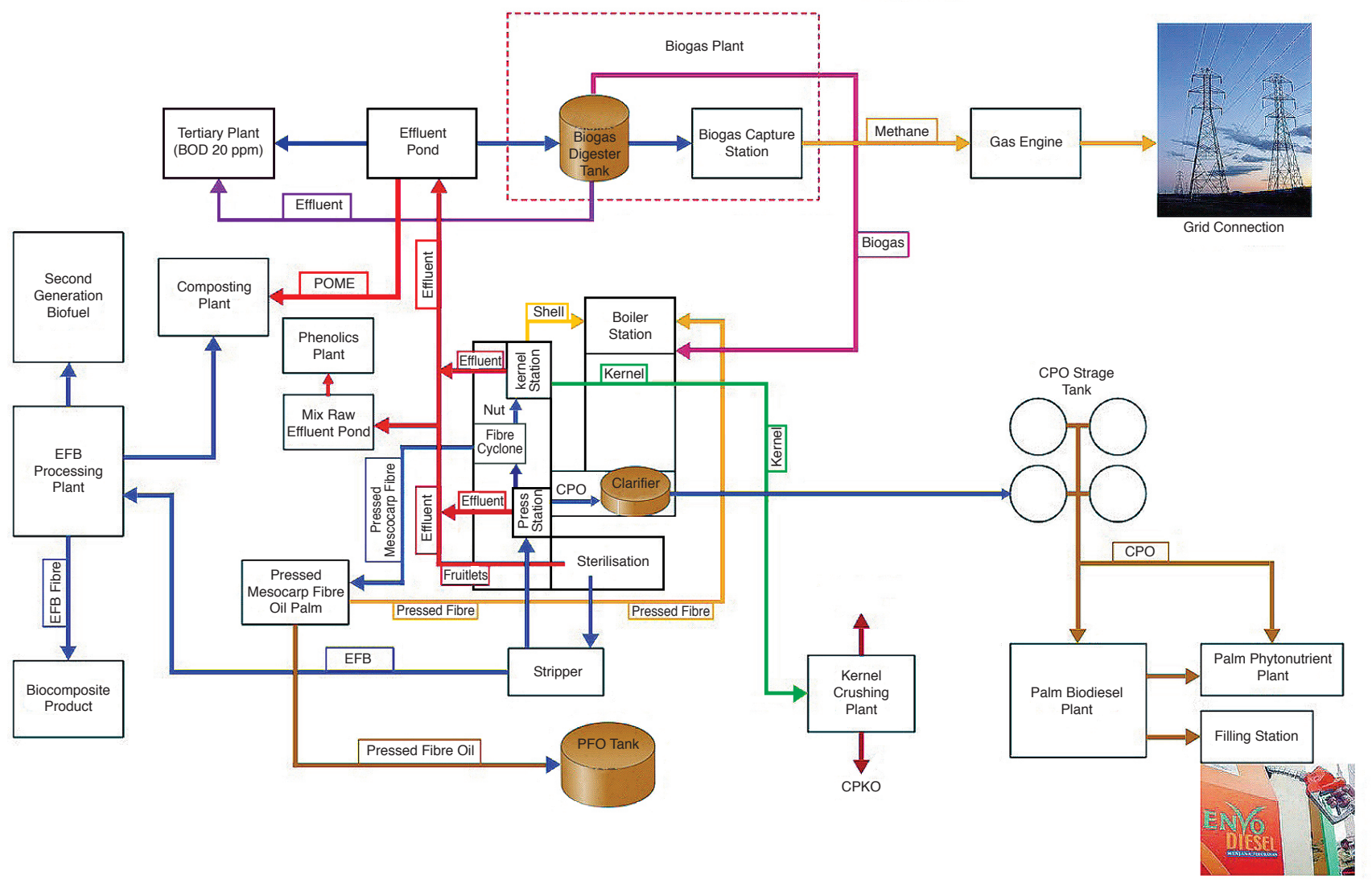

Note: POME - palm oil mill effluent; EFB - empty fruit bunches; CPO - crude palm oil; CPKO - crude palm kernel oil; PFO - pressed fibre oil.

Figure 3. A proposed palm oil mill-based biorefinery.

on a value/supply chain-based life cycle analysis. The study recommended the use of supply chain management best practices to tackle issues on carbonwastewater, fertiliser, and energy-fertiliser. In Indonesia, a first of its kind fine-spatial calculation of GHG footprints of CPO was conducted at different level of administrative regions (Lam et al., 2019). Intended companies can use the results to screen for new oil palm concessions and commodity sourcing before investing heavily in other required sustainability assessments. Separately in Malaysia, assessment was done on identifying the uncertainties and biasness of the inclusion of indirect land use change into the European Union Renewable Energy Sources Directive (EU RED) II against palm oil (Subramaniam et al., 2019a). The uncertainties in the Commission Delegated Regulation could directly be construed as a form of trade barriers with strong political influences. This kind of unpopular requirement would have indirect interconnection between climate change politics and land grabs which might significantly impart social relations, nature and land use change calling for better understanding and knowledge enhancement to achieve a common global interest
(Franco and Borras, 2019). More engagement needs to be performed to avoid any unintended lopsided policy interventions.

\section{Food Safety and Nutrition Issues Surrounding Palm Oil}

As the world approaches the remaining decade in its quest to achieve the 17 United Nations Sustainable Development Goals (SDG) by 2030, the palm oil industry has steered proactively in its efforts to ensure the world is supplying sustainable palm oil and palm-based products for food and nutrition. This is in line with SDG2 focusing on ending hunger and malnutrition, boosting agriculture productivity and enhancing sustainable food systems, in addition to SDG3 to ensure healthy lives and promote well-being for all at all ages (Fanco and Borras, 2019). The diversification of palm oil as a food ingredient has contributed significantly in enhancing food security, health and well-being of millions of people around the world in pursuit of sustainable food production and healthy diets (Willet et al., 2019). This is evident from a recent comprehensive review on available 
scientific evidence about the role of palm oil in food safety, nutrition and sustainability by Gesteiro et al. (2019) which concluded that consumption of palm oil in moderate amounts within a balanced diet does not present any health risks and that there were no scientific or epidemiological evidence to associate palm oil consumption with a higher risk of cancer incidence and mortality in humans.

Palm oil has long been regarded as one of the most popular vegetable oils used for frying as it possesses excellent thermal and oxidative stability compared to other vegetable oils. However, the longstanding practice of repeated usage of frying oils in the food services industry has raised concerns over the quality and safety aspects of frying oils, hence, making it imperative for close quality monitoring to ensure frying oil deterioration is kept to a minimum. The formation of polar compounds in different frying oils under simulated frying practice of fast food restaurants was investigated by Ahmad Tarmizi et al. (2019) using palm olein, soyabean oil, canola oil, sunflower oil and binary/ternary blends of the unsaturated oils with palm olein. Their study found that liquid oils containing the same levels of polyunsaturated fatty acids (PUFA) were found to exhibit similar rates of oxidised and polymerised TAG, with polymerised TAG levels of 1.6-2.4 times higher than palm olein and suggested that unsaturated vegetable oils could be blended with palm olein to control polymerised TAG formation during frying. Li et al. (2019a) also demonstrated that the type of frying oil plays a significant role in the distribution of polar compounds in discarded oil during deep frying at commercial scale and the content of oxidised triglyceride monomer, the compound of greatest concern, was lowest in palm oil compared to other vegetable oils such as cottonseed oil, soyabean oil, canola oil and high oleic sunflower oil evaluated in their study. Prolonged consumption of oxidised and degraded frying oils through its absorption in food products may induce inflammation, increase cancer risks due to inflammation and further promote tumour growths as reviewed by Yee and Tiu (2019). Thus, utilising palm-based frying oils and fats during food preparation is highly recommended to minimise lipid peroxidation in the oil used to fry foods and to avoid the generation of toxic compounds which can be detrimental to health.

Recent advances in analytical techniques for monitoring palm oil quality parameters has led to innovative and reliable analytical instruments and methods that are rapid, convenient and efficient in analysing palm oil products, therefore ensuring palm oil consumed worldwide conforms to international food trade standards and national legislations. Kaufmann et al. (2019) demonstrated that portable near-infrared (NIR) spectrophotometers can be used as a low-cost, rapid and non-destructive technique to predict the free fatty acids of palm oil. A simple and reliable method for the determination of paraquat residues in palm oil products was established by Halim et al. (2019) using high performance liquid chromatography-ultra violet detection and liquid chromatography with mass spectrometry (LCMS/MS). The method complies with regulatory maximum residue limits and is suitable for commercial residue testing with high throughput. The application of attenuated total reflectionFourier transform infrared spectrometer (ATRFTIR) in combination with chemometrics analysis for estimating 3-monochloropropanediol esters (3-MCPDE) levels in palm olein was demonstrated by Wong et al. (2019a) and FTIR results were found to be consistent with that of the indirect method by gas chromatography-mass spectrometry (GC-MS) as an alternative technique for rapid qualitative and quantitative analysis of 3-MCPDE content in oil.

More recent attention has been focused on monitoring changes in 3-MCPDE, glycidyl esters (GE) and other process-induced contaminants during various cooking methods such as deep-fat frying and baking. In a study by Ahmad Tarmizi et al. (2019) on the effects of polyglycerol fatty acid esters (PGE) on 3-MCPDE and GE formation in palm olein during repeated frying, it was reported that increasing PGE dosage delayed the reduction of these contaminants and induced a higher formation of polar compound fractions with increasing frying times. Their study also found that the presence of chloride in palm olein did not cause further formation of 3-MCPDE and GE and recommended that only a sufficient amount of PGE should be added into palm olein to delay cloudiness. The effects of various natural and synthetic antioxidants, namely butylated hydroxyanisole (BHA), butylated hydroxytoluene (BHT), tert-butylhydroquinone (TBHQ), oleoresin rosemary and sage extract on changes in 3-MCPDE and GE in palm olein during the deep-fat frying of potato chips was investigated by Wong et al. (2019b). Antioxidant usage was found to aid in the reduction of 3-MCPDE and GE during deep-fat frying through oil stability improvement and the order of effectiveness of antioxidants was $\mathrm{BHT}<\mathrm{BHA}<$ sage extract $<$ oleoresin rosemary<TBHQ. Goh et al. (2019) found that the 2- and 3-MCPDE in a conventional cake baked with different palm-based shortenings were stable regardless of baking temperatures between $160^{\circ} \mathrm{C}$ and $200^{\circ} \mathrm{C}$; however, GE content decreased upon baking and more so in margarine and soft stearin samples. This was due to the instability of GE which increases in degradation rate with increasing baking temperature.

A comprehensive review on strategies for reducing the formation of 2- and 3-MCPDE and GE during vegetable oil refining by Oey et al. (2019) recommended a combination of mitigation 
strategies at different refining steps to adequately reduce the levels of these process contaminants. Most notably were water washing for removing chlorine precursors, pre-heat treatment $\mathrm{pH}$ neutralisation and double-deodourisation as well as usage of absorbents, enzymes and re-bleaching the oil post-refining. Silva et al. (2019) reported that a double washing procedure performed on bleached palm oil using ethanol $99.5 \%$ in the first step and aqueous ethanol and water solutions (at 10\% and $40 \%$ ethanol) in the second step caused a significant reduction in GE levels (76.9\%) while 3-MCPDE and 2-MCPDE levels were slightly reduced by up to $17.1 \%$ and $56.4 \%$, respectively. Their study suggested washing treatment as an additional strategy for reducing process contaminants from palm oil. An assessment of 3-MCPDE and GE in palm products from different regions in Malaysia conducted by Abd Razak et al. (2019) revealed that only one refinery amongst the sampling regions displayed a significant increase in 3-MCPDE and GE levels at $1.3 \mathrm{mg} \mathrm{kg}^{-1}$ and $2.5 \mathrm{mg} \mathrm{kg}^{-1}$, respectively. Their results suggest that there was no correlation between esters and total chlorine content amongst the different sampling locations in Malaysia.

\section{Nutrition and Food Development}

It is well documented in the literature that palm oil contains an abundance of phytonutrients such as tocotrienols, carotenes, polyphenols, phytosterols and squalene. These phytonutrients are beneficial to health and offer protection, prevention and treatment for various non-communicable diseases (Gupta et al., 2019; Sambanthamurthi et al., 2019; Syarifah-Noratiqah et al., 2019; Zhou et al., 2019). A recent meta-analysis on the intake of palm olein and lipid status in healthy adults by Voon et al. (2019) indicated that palm olein had comparable effects with monounsaturated fatty acid (MUFA)-rich and PUFA-rich vegetable oils on blood cholesterol and lipid profiles. Their study further suggested that palm olein does not behave similarly to a saturated fatty acid (SFA)-rich fat due to the location of SFA in palm olein which mainly occupy the $s n-1$ and $s n-3$ positions on the TAG backbone. Studies on the anti-cancer effects of palm tocotrienol rich fraction (TRF) was recently highlighted in a review by Subramaniam et al. (2019b) where tocotrienols were shown to possess anti-tumour properties in prostate, breast, skin, colon, stomach, pancreatic, liver and lung cancers through apoptosis, anti-angiogenesis, anti-proliferative and immunoregulation. Zaulkffali et al. (2019) found that palm TRF reduces oxidative stress which occurs during insulin resistance in an in vitro model study on hyperinsulinaemia in neuronal cells, suggesting the potential therapeutic role of palm TRF in improving neuronal insulin resistance and Alzheimer's disease. A study by Zainal et al. (2019a) on the effects of palm TRF and carotenes in asthmatic brown rats showed that TRF-treated rats displayed noticeable increases in anti-inflammatory markers while pro-inflammatory markers decreased with improvements in lung function, further suggesting that palm TRF and carotene may play an important role in bronchial asthma management due to their potent natural antioxidant properties. Another in vivo investigation into the therapeutic effects of palm TRF on rheumatoid arthritis by Zainal et al. (2019b) showed that collagen-induced arthritic rats supplemented orally with palm TRF had reduced inflammation in arthritic joints in the paws compared to untreated rats and suggested that TRF may act as a potential anti-arthritic agent and reduce arthritis-related inflammation. The potential role of tocotrienols in modulating the life or death decision of cancer cells was recently reviewed by Tham et al. (2019) where tocotrienols were found to induce cell death by modulating various mechanisms such as apoptosis and autophagy in cancer, highlighting the advantages of combining tocotrienols with anti-cancer agents on various types of cancers. Palm TRF has also shown effectiveness in treating breast cancer in mice through a daily palm TRF supplementation combined with dendritic cell (DC)-vaccine immunotherapy that was able to reduce tumour size significantly and increase the survival rate of breast cancer-induced mice through inhibition of tumour growth and metastasis (Abdul Hafid and Radhakrishnan, 2019). These studies provide further evidence on the potential health benefits of palm TRF as a natural defense against Alzheimer's, asthma, arthritis and cancer.

Research concentrated on developing useful new ingredients derived from palm oil for application in functional foods and nutritional supplements are also being undertaken. The synthesis of palm oil-omega-3 structured lipids was recently conducted by Xia et al. (2019c). Candida antartica lipase was employed to partially hydrolyse palm oil while Lipozyme RMIM from Rhizomucor miehei was then used to incorporate $\alpha$-linolenic acid (ALA) or eicosapentaenoic acid (EPA) into palm oil TAG structure. Their study resulted in new palm oil-structured lipids containing 50\% lower SFA and lower melting points of $8^{\circ} \mathrm{C}$. The utilisation of oil palm phenolic (OPP) compounds extracted from palm kernel cake and palm pressed fibre as an antioxidant in sunflower oil was recently explored by Tsouko et al. (2019). OPP was found to be comparable to that of BHA, further demonstrating their potential application as antioxidants in the food industry.

$\mathrm{CPO}$ is well-known for its abundance in micronutrient content, particularly TRF. However, little is known about its stability when formulated into powdered microencapsulated palm TRF as chewable tablet, another form of dietary supplement. 
Habi Mat Dian et al. (2019a) studied the stability of these supplement for a duration of one year storage period at room temperature. The technology has successfully retained $92.6 \%$ of palm TRF in the chewable tablet. On the other hand, analysis of two commercially available chewable tablets showed that $100 \%$ loss were observed after 10 and 14 months of their manufacturing dates.

In addition to the continuous efforts to secure the food industry by enhancing the versatility of palm oil for diversified food applications, there have been latest developments globally in seeking alternatives to partially hydrogenated fats to accomplish the call from the World Health Organisation (WHO) for global trans-fat elimination by 2023 (Li et al., 2019b). Palm oil products have been known as excellent replacers for trans-fat in food formulations as palm oil solid fractions are naturally high melting and possess improved oxidative stability compared to other oils. Production of trans-fat replacers can be achieved through established palm oil modification techniques such as blending palm oil with other oils and interesterification with different fats to alter the physical properties and produce fats with improved functionality in various food applications (Berry et al., 2019). Enzymatic directed interesterification (EDIE) of palm oil was recently explored by Habi
Mat Dian et al. (2019b) as a tool for modifying the TAG composition of palm oil and they observed a significant increase in triunsaturated and trisaturated TAG in palm oil after EDIE. Using differential scanning calorimetry, their study revealed two well-separated olein and stearin components in palm oil upon EDIE as shown in Figure 4, of which when fractionated would yield a high oleic acid olein fraction and a high palmitic acid stearin fraction dominated by $\beta$ crystals and suitable to be used as a trans-free structural fat. Liu et al. (2019) comparatively analysed binary and ternary blends of palm kernel oil, palm kernel stearin and palm stearin and found that palm kernel stearin/palm stearin blends containing less than $50 \%$ palm stearin were suitable for cream production as they were found to melt completely at body temperature while ternary blends with more than $80 \%$ palm kernel stearin were better formulations for shortenings and margarines due to their improved plasticity and spreadability. Enzymatically interesterified fat blends containing beef tallow, camellia oil and palm stearin at a ratio of 7.55:2.45:4 were found to produce the desirable $\beta^{\prime}$ crystal type and a projected antioxidative stability of up to 352 days at $20^{\circ} \mathrm{C}$, thus making it suitable as an alternative source of transfree plastic fat stock (Pang et al., 2019).

(a)

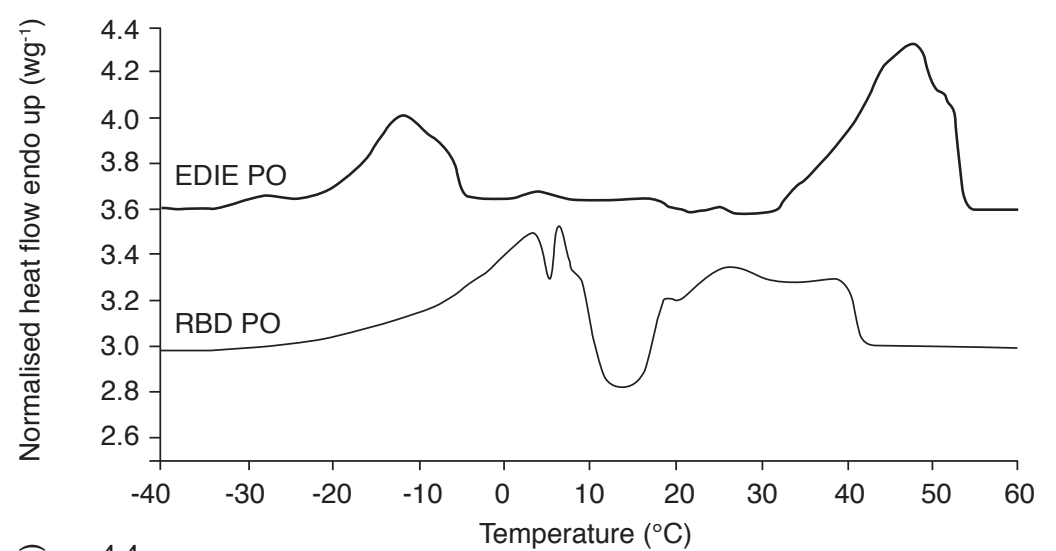

(b)

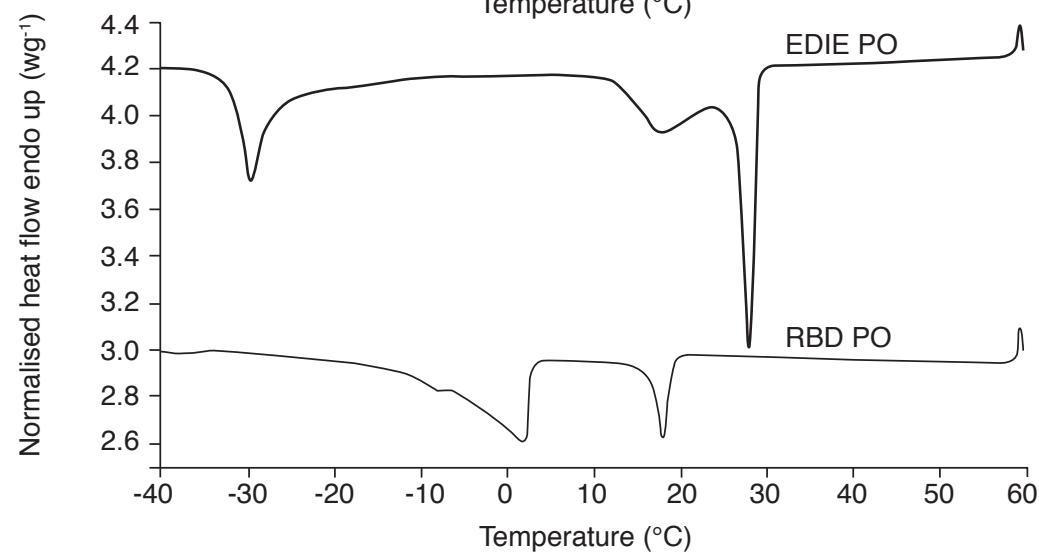

Source: Habi Mat Dian et al. (2019a).

Figure 4. Differential scanning calorimetry melting (a) and crystallisation (b) thermograms of enzymatic directed interesterified palm oil (EDIE PO) and refined, bleached and deodourised palm oil (RBD PO). 


\section{Oleochemical Developments}

The Malaysian oleochemical industry had undergone rapid growth and development, and today the industry is one of the world's largest producers of oleochemicals, accounting for 20\% of the world's basic oleochemical capacity. In Malaysia, the oleochemical industry is almost totally dependent on palm oil/palm kernel oil as the major feedstocks. Therefore, it plays a vital role in supporting the local palm oil industry as well as adding significant value to palm products. There are currently 19 oleochemical plants operating in Malaysia, which exported approximately 3.28 million tonnes of oleochemicals in 2019 (MPOB, 2020). The global oleochemical market is estimated to grow at a Compound Annual Growth Rate (CAGR) of 5.05\% during the forecast period to reach USD 24.208 billion by 2023, increasing from USD 18.920 billion in 2018 (Research and Markets, 2020). The Asia-Pacific region is estimated to be the fastestgrowing region as a result of the easy availability of raw material and the development of newer applications for the product. The global oleochemical is highly competitive owing to the presence of well-diversified multinationals, regional and local players. The use of oleochemical compounds in the daily life of a consumer such as personal and household products are attracting new players in the market, enhancing the competitive rivalry. The growing demand for sustainable consumer products coupled with the stringent regulations in recent years has increased the influence of oleochemicals in various industries. Recent $R \& D$ efforts have focused more on the development of products utilising various oleochemical derivatives such as bio-polyol for polyurethanes, surfactants and biosurfactants, biolubricant and glycerol derivatives.

One of the promising areas is polyurethane, which has diverse applications ranging from the versatile foams to sophisticated medical devices. Polyurethane is conventionally produced from petrochemicals but the industry is in the need to go for bio-based materials and palm kernel oil, fatty acid methyl ester and oleic acid. Palm-based polyurethane is highly desirable to reduce the dependency on petroleum-based raw materials. Thermoplastic polyurethane or TPU is one of the major categories of polyurethane with diverse applications. TPU is referred to as the bridge between rubber and plastic. The material appears rubber-like, which means it can be extremely flexible, durable and smooth to the touch. All these properties and compound versatility make TPU widely used in many industries for coatings, components and consumer goods. Polyester polyols from renewable resources have gained significant interest in the field of polyurethane chemistry (Norhayati et al., 2016; Alagi et al., 2017;
Kamaruzaman et al., 2019). Tuan Noor Maznee et al. (2019) had successfully evaluated the effect of crystalline and amorphous azelate polyols on the structure-properties relationship of thermoplastic polyurethanes. Thermoplastic polyurethanes based on crystalline azelate polyols exhibited higher mechanical properties, better heat resistance and lower heat build-up compared to amorphous azelate polyols. The study suggested that crystalline azelate polyols are suitable for dynamic application of TPU, and amorphous azelate polyols are suitable for coatings and adhesives applications.

Increasing environmental awareness and global climate change has shifted the attention from using petroleum-based materials towards more biodegradable and renewable materials. In addition, stringent regulations have accelerated the adoption of bio-based lubricants. Vegetable oils have been used as environmental-friendly biolubricants because of their inherent biodegradability, lubricity, higher viscosity index, and low evaporative loss (McNutt and He, 2016). However, their use is limited due to significantly poor cold flow properties and inferior oxidative stability. Recent developments in this field have shown that palm-based lubricants can be synthesised with comparable oxidative stability, viscosity index and anti-wear properties as to commercial lubricants (Zainal et al., 2018). Hoong et al. (2019) has successfully synthesised novel lauric acid capped estolide esters and amides made from oleic acid, with improved cold flow properties compared to vegetable oil-based lubricants (Figure 5). The estolide amides exhibited higher oxidative stability with an oxidation onset temperature of $205^{\circ} \mathrm{C}$ compared to other vegetable oil-based lubricants.

In another development, dimerate esters have been synthesised using a catalyst and solventfree approaches. The dimerate esters have high viscosity indices ranging between 129 and 138 and are comparable with two commercial base stocks, polyalpha olefin and polyol ester (Armylisa's et al., 2019). The pour point is less than $-42^{\circ} \mathrm{C}$ for di(2-ethylhexyl) dimerate, which is attributed to the branching of the side chain. The dimerate esters have high potential to be used as lubricant base stock for equipment and machinery operating at extremely low temperatures. Cheong et al. (2019) have also successfully synthesised and characterised another form of bio-based polymer, epoxidised trimethylolpropane trioleate, with potential application as a biolubricant and a feedstock for the production of coatings.

The demand for environmental-friendly products has encouraged the development of new materials in the field of phase change material (PCM). The PCM releases or absorbs significant amounts of thermal energy per unit mass at a relatively constant temperature at phase transition to 


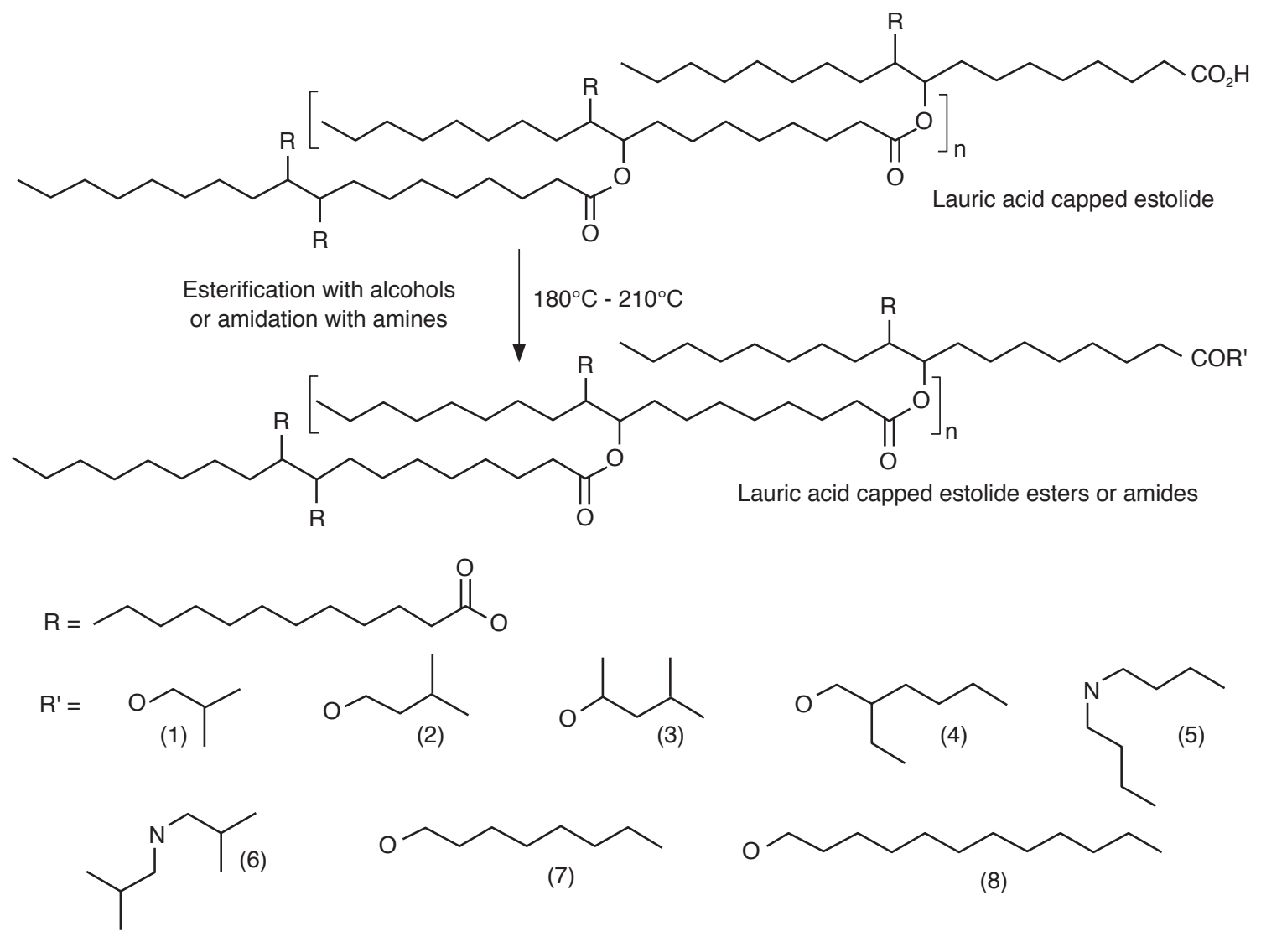

Source: Hoong et al. (2019).

Figure 5. Synthesis of lauric acid capped estolide esters and amides.

provide useful heat or cooling properties. Currently, most of the commercial phase change materials are derived mainly from petroleum feedstock (i.e, paraffin) and inorganic salts. However, Kyriaki et al. (2018) have shown that the use of paraffin as phase change materials in building applications have a negative impact on the environment. Therefore, substitutes from renewable feedstock with positive environmental impact are highly desirable, such as vegetable oil triglycerides. Kosheela et al. (2019a, b) have investigated and found that linear aliphatic saturated amides with differing chain length and symmetry can be used as efficient thermal energy storage materials (Table 14). The amides were thermally stable up to at least $325^{\circ} \mathrm{C}$ and presented thermal transition temperatures between $138^{\circ} \mathrm{C}$ and $152^{\circ} \mathrm{C}$ with a thermal storage density of $\sim 220 \mathrm{~J} \mathrm{~g}^{-1}$, which are amongst the highest currently accessible by organic phase change materials. This makes them useful as thermal energy storage materials, e.g., for the management of intermittent renewable energy, battery thermal management for electric vehicles, and reusable industrial and building waste heat.

There is an increasing trend of chemical industries toward new processes that should meet stringent environmental or energy requirements such as the generation of nearly zero waste chemicals, less energy, and sufficient uses of product chemicals in various applications. Microwave irradiation has been applied to speed up the heating process compared to conventional heating in a catalytic reaction (Leadbeater and Stencel, 2006; Vidya, 2015). Noor Azeerah et al. (2019) has successfully utilised microwave heating for high conversion of lauric acid into glycol esters via esterification with diethylene glycol, aided by calcined $\mathrm{Zn}-\mathrm{Mg}-\mathrm{Al}$ catalyst. The newly synthesised glycol esters have broad applications as emulsifiers for household and personal care products, as coalescent aid in paint formulations, additives for engine oil and biolubricants.

In the area of surfactant, methyl ester sulphonate, which is an anionic surfactant derived from palm oil has been commercially used as the main active ingredient for detergents. It is better tolerant to hard water, better detergency at low temperature, and is biodegradable. The global market size was valued at USD 0.57 billion in 2015 and is likely to reach a size of USD 2.2 billion by 2024 (Global Market Insight, 2020). The product proves to be an environmentalfriendly and feasible alternative to presently used surfactant, linear alkyl benzene sulphonate. They are produced by sulphonation of saturated methyl esters with sulphur trioxide. During this process, 
TABLE 14. IUPAC NAME, MOLECULAR FORMULA AND STRUCTURE OF THE MONOAMIDES

\begin{tabular}{|c|c|c|}
\hline IUPAC name & Molecular formula & Generalised structure \\
\hline$N$-hexadecyl-decanamide & $\mathrm{C}_{26} \mathrm{H}_{53} \mathrm{NO}$ & $\mathrm{H}$ \\
\hline$N$-hexadecyl-dodecanamide & $\mathrm{C}_{28} \mathrm{H}_{57} \mathrm{NO}$ & \\
\hline$N$-hexadecyl-tetradecanamide & $\mathrm{C}_{30} \mathrm{H}_{61} \mathrm{NO}$ & \\
\hline$N$-hexadecyl-palmitamide & $\mathrm{C}_{32} \mathrm{H}_{65} \mathrm{NO}$ & \\
\hline$N$-hexadecyl-stearamide & $\mathrm{C}_{34} \mathrm{H}_{69} \mathrm{NO}$ & \\
\hline$N$-octadecyl-stearamide & $\mathrm{C}_{36} \mathrm{H}_{73} \mathrm{NO}$ & \\
\hline
\end{tabular}

Note: IUPAC - International Union of Pure and Applied Chemistry.

Source: Kosheela et al. (2019b).

some side reactions may occur to form by-products. One of the potential by-products that may be present is dimethyl sulphate (DMS) (Foster et al., 2009). Recently, Bonnie and Haliza (2019) have successfully developed a new and simple method for detection and quantification of DMS. All palm methyl ester sulphonates of different chain lengths including commercial samples, were free from DMS. The new test method can be applied by the methyl ester sulphonate manufacturers to monitor the presence of undesirable by-products. In another development, mixed surfactants of polyoxyethylene (20) sorbitan monooleate and $\mathrm{C}_{12}-\mathrm{C}_{14}$ fatty alcohol ethoxylate exhibited superior emulsification efficiency and stability (Sumaiyah et al., 2019). The formulation with methyl esters as a carrier solvent opens the possibility of using palm-based surfactants and esters in insecticide emulsions to curb the spread of mosquito-borne diseases.

\section{CONCLUSION}

In conclusion, the year 2019 was a turning point to the Malaysian palm oil industry with additional challenges in the upstream, midstream and downstream being identified. Research was strengthened focusing on the two most prominent components of the sustainable development pillars; people and environment. Efforts were intensified on the ground targeting the smallholders to be sustainable and at the same time increasing their income. This was strategically executed in phases through the national effort namely MSPO for the former and research on integrated farming on the latter. The halting of peat cultivation and implementation of environmental-centric policies have further substantiated the Malaysian palm oil industry's determinations in facing the challenges. Unrelenting to these damaging developments harassing the oil palm industry locally and internationally, the industry has been resilient by actively conducting R\&D activities addressing the global concerns. Other environmental issues such as climate change and biodiversity were the key elements in most of the article published in 2019. Undeniably, the impact observed PSF and forest conversion have been proven to negatively distress the environment with evident biodiversity loss and GHG emission upsurge which in turn has the industry restricting further peat cultivation.

Over the past few decades, R\&D activities within the industry revolved on leveraging the biotechnological advances to improve oil palm yield while P\&D challenges were attended through greener approaches and integrated management. Taking into consideration that mechanisation will provide the much-needed improvement in productivity owing to the scarcity of labour, efforts has to be multiplied to deliver the desirable transformation. The industry continues to strive by providing best quality oil and exploring new market through price and customer needs sensitivity. Similarly, the downstream sectors such as food and nutrition benefits require more international recognitions and clinical collaborations. The year 2019 has also seen more non-food and 
bio-based materials research being intensified with more environmental-friendly household products produced. This positive development needs to be strongly encouraged combined with sustainable sources and practices. Although there is still a lot need to be done to remain viable and sustainable, the industry continues to victoriously face the challenges ahead and thrive for excellence.

\section{ACKNOWLEDGEMENT}

The authors wish to thank all from the different divisions in MPOB for their contribution to this article.

\section{REFERENCES}

Abd Latif, N H; Abdul Rahim, A; Brosse, N and Hussin, M H (2019). The structural characterization and antioxidant properties of oil palm fronds lignin incorporated with p-hydroxyacetophenone. International J. Biological Macromolecules, 130: 947-957.

Abd Razak, R A; Ahmad Tarmizi, A H; Abdul Hammid, A N; Kuntom, A; Ismail, I S and Sanny, M (2019). Verification and evaluation of monochloropropanediol (MCPD) esters and glycidyl esters in palm oil products of different regions in Malaysia. Food Additives and Contaminants, 36(11): 1626-1636.

Abdul Hadi, N; Hawari, Y; Ngatiman, M; Jalani, N F; Abdul Wahab, N and Mohamed Halim, R (2019). Assessment of the effluent polishing plant using an ultrafiltration membrane installed at a palm oil mill. Environment Protection Engineering, 45(1): 155-170.

Abdul Hafid, R S and Radhakrishnan, A K (2019). Palm tocotrienol-adjuvanted dendritic cells decrease expression of the SATB1 gene in murine breast cancer cells and tissues. Vaccines, 7(4): 198. DOI: $10.3390 /$ vaccines7040198.

Adnan, W; Islam, W; Shabbir, A; Khan, KA; Ghramh, H A; Chen, H Y H and Lu, G D (2019). Plant defense against fungal pathogens by antagonistic fungi with Trichoderma in focus. Microbial Pathogenesis, 129: 7-18.

Afriyanti, D; Hein, L; Kroeze, C; Zuhdi, M and Saad, A (2019). Scenarios for withdrawal of oil palm plantations from peatlands in Jambi Province, Sumatra, Indonesia. Regional Environmental Change, 19(4): 1201-1215.

Ahmad Farid, M A; Roslan, A M; Hassan, M A; Aziz Ujang, F; Mohamad, Z; Hasan, M Y and Yoshihito, $S$ (2019). Convective sludge drying by rotary drum dryer using waste steam for palm oil mill effluent treatment. J. Cleaner Production, 240: 117986. DOI: 10.1016/j.jclepro.2019.117986.

Ahmad Tarmizi, A H; Razak, A; Arni, R; Hammid, A; Niefaizal, A and Kuntom, A (2019). Effect of anticlouding agent on the fate of 3-monochloropropane-1, 2-diol esters and glycidyl esters in palm olein during repeated frying. Molecules, 24(12): 2332. DOI: 10.3390 / molecules24122332.

Ahmad, F B; Zhang, Z; Doherty, W O S and O'Hara, I M (2019a). The prospect of microbial oil production and applications from oil palm biomass. Biochemical Engineering J., 143: 9-23.

Ahmad, F B; Zhang, Z; Doherty, W O S and O'Hara, I M (2019b). The outlook of the production of advanced fuels and chemicals from integrated oil palm biomass biorefinery. Renewable and Sustainable Energy Reviews, 109: 386-411.

Alagi, P; Ghorpade, R; Choi, Y J; Patil, U; Kim, I; Baik, J H and Hong, S C (2017). Carbon dioxide-based polyols as sustainable feedstock of thermoplastic polyurethane for corrosion-resistant metal coating. ACS Sustainable Chemistry and Engineering, 5: 38713881.

Anamulai, S; Sanusi, R; Zubaid, A; Lechner, A M; Ashton-Butt, A and Azhar, B (2019). Land use conversion from peat swamp forest to oil palm agriculture greatly modifies microclimate and soil conditions. PeerJ., 7: e7656.

Armylisa's, A H N; Fauzi, S H M; Khairin, M N; Yeong, S K; Idris, Z and Azwadi, C S N (2019). Excellent properties of dimer fatty acid esters as biolubricant produced by catalyst and solvent free esterification. European J. Lipid Science and Technology, 121(11): 1900228. DOI: 10.1002 / ejlt.201900228.

Ashton Butt, A; Willcock, S; Purnomo, D; Aryawan, A A; Wahyuningsih, R; Naim, M; Poppy, G M; Caliman, J P; Peh, K S and Snaddon, J L (2019). Replanting of first cycle oil palm results in a second wave of biodiversity loss. Ecology and Evolution, 9(11): 6433-43.

Astorkia, M; Hernandez, M; Bocs, S; De Armentia, E L; Herran, A; Ponce, K; León, O; Morales, S; Quezada, N; Orellana, F; Wendra, F; Sembiring, Z; Asmono, D and Ritter, E (2019). Association mapping between candidate gene SNP and production and oil quality traits in interspecific oil palm hybrids. Plants, 8: 377. DOI:10.3390/ plants8100377.

Awang, A; Hashim, K; Ramli, Z and Ibrahim, I (2016). Agriculture technology transfer and productivity 
of independent oil palm smallholders. Proc. of the Academics World 55 th International Conference. Auckland, New Zealand. p. 1-6.

Azian, F U M; Awang, A H; Ibrahim, I; Ramli, Z; Lyndon, N; Yusof, I; Hashim, K; Tan, S P; Johari, M A; Basaruddin, N H and Hamid, M H A (2017). Kelestarian penanaman sawit dan produktiviti pekebun kecil persendirian. J. Global Business and Social Entrepreneurship (GBSE), 1(1): 12-20.

Azuan, N H; Khairunniza-Bejo, S; Abdullah, A F; Kassim, M S M and Ahmad, D (2019). Analysis of changes in oil palm canopy architecture from basal stem rot using terrestrial laser scanner. Plant Disease, 103 (12): 3218-3225.

Berry, S E; Bruce, J H; Steenson, S; Stanner, S; Buttriss, J L; Spiro, A; Gibson, P S; Bowler, I; Dionisi, F; Farrell, L and Glass, A (2019). Interesterified fats: What are they and why are they used? A briefing report from the roundtable on interesterified fats in foods. Nutrition Bulletin, 44: 363-380.

Bonnie, T Y P and Haliza, A A (2019). A new gas chromatography-mass spectrometry method for detecting and quantifying low levels of dimethyl sulfate in palm oil based sulfonated methyl esters. J. Surfactants and Detergents, 22(4): 751-756.

Brinkmann, N; Schneider, D; Sahner, J; Ballauff, J; Edy, N; Barus, H; Irawan, B; Budi, S W; Qaim, M; Daniel, R and Polle, A (2019). Intensive tropical land use massively shifts soil fungal communities. Scientific Reports, 9: 3-11.

Bukhari, N A; Loh, S K; Nasrin, A B; Indera Luthfi, A A; Harun, S; Mohamed Abdul, P and Md Jahim, J (2019). Compatibility of utilising nitrogen-rich oil palm trunk sap for succinic acid fermentation by Actinobacillus succinogenes 130Z. Bioresource Technology, 293: 122085. DOI: 10.1016/j. biortech.2019.122085.

Charters, L J; Aplin, P; Marston, C G; Padfield, R; Rengasamy, N; Bin Dahalan, M P and Evers, S (2019). Peat swamp forest conservation withstands pervasive land conversion to oil palm plantation in North Selangor, Malaysia. International J. Remote Sensing, 40(19): 7409-7438.

Cheong, M Y; Zafarizal, A A H and Zainab, I (2019). Characterisation of epoxidised trimethylolpropane trioleate: NMR and thermogravimetric analysis. J. Oil Palm Res.Vol. 31(1): 146-158.

Chung, Z L; Tan, Y H; Chan, Y S; Kansedo, J; Mubarak, N M; Ghasemi, M and Abdullah, M O (2019). Life cycle assessment of waste cooking oil for biodiesel production using waste chicken eggshell derived $\mathrm{CaO}$ as catalyst via transesterification. Biocatalysis and Agricultural Biotechnology, 21: 101317. DOI: 10.1016/j.bcab.2019.101317.

Cooper, H V; Evers, S; Aplin, P; Crout, N; Dahalan, M P B and Sjogersten, S (2020). Greenhouse gas emissions resulting from conversion of peat swamp forest to oil palm plantation. Nature Communications, 11(1): 1-8.

Corley, R H V (2018). Does the RSPO have a future? Costly criteria inadequate returns. Global Oils $\mathcal{E}$ Fats Business Magazine, 15(4): 13-18.

Da Silva, A C; Grativol, C; Thiebaut, F; Hemerly, A S; Cavalcanti, P and Ferreira, G (2016). Computational identification and comparative analysis of miRNA precursors in three palm species. Planta, 243: 12651277. DOI: 10.1007 / s00425-016-2486-6.

Darras, K F; Corre, M D; Formaglio, G; Tjoa, A; Potapov, A; Brambach, F; Sibhatu, K T; Grass, I; Rubiano, A A; Buchori, D and Drescher, J (2019). Reducing fertilizer and avoiding herbicides in oil palm plantations - Ecological and economic valuations. Frontiers in Forests and Global Change, 2(65): $1-5$.

De Menezes Nogueira, I; Avelino, F; De Oliveira, D R; Souza, N F; Rosa, M F; Mazzetto, S E and Lomonaco, D (2019). Organic solvent fractionation of acetosolv palm oil lignin: The role of its structure on the antioxidant activity. International J. Biological Macromolecules, 122: 1163-1172.

Dubos, B; Baron, V; Bonneau, X; Dassou, O; Flori, A; Impens, R; Ollivier, J and Pardon, L (2019). Precision agriculture in oil palm plantations: Diagnostic tools for sustainable $\mathrm{N}$ and K nutrient supply. Oilseeds and Fats, Crops and Lipids, 26(5): 1-8.

European Palm Oil Alliance (2016). The palm oil story. https:// issuu.com/epoa/docs/brochure palm_oil_story_def_online_c6305acc5b0a30 $? \mathrm{e}=25838315 / 61064871$, accessed on 1 April 2020.

Fanzo, J (2019). Healthy and sustainable diets and food systems: The key to achieving sustainable development goal 2? Food Ethics, 4: 159-174.

Farah, A M P; Sundram, S; Mohd Termizi Y; Angel, L P L; Amalia, M H and Siti Nor Akmar, A (2019). Induced systemic resistance and promotion of plant growth in oil palm seedlings by endophytic Trichoderma virens. J. Oil Palm Res. Vol. 31(4): 572-581.

Flusberg, B A; Webster, D R; Lee, J H; Travers, K J; Olivares, E C; Clark, T A; Korlach, J and Turner, S W 
(2010). Direct detection of DNA methylation during single-molecule, real-time sequencing. Nature Methods, 7: 461-465.

Foster, N C; MacArthur, B W; Sheats, W B; Shea, M C and Trivedi, S N (2009). Chapter 11: Production of methyl ester sulfonates. Handbook of Detergents. Part F: Production (Zoller, U and Sosis, P eds.). New York, CRC Press. p. 201-219.

Franco, J C and Borras, J S M (2019). Grey areas in green grabbing: Subtle and indirect interconnections between climate change politics and land grabs and their implications for research. Land Use Policy, 84: 192-199.

Gao, L C; Wang, Y F; Zhu, Z; Chen, H; Sun, R H; Zheng, Y S and Li, D D (2019). EgmiR5179 from the mesocarp of oil palm (Elaeis guineensis Jacq.) regulates oil accumulation by targeting NAD transporter 1. Industrial Crops E Products, 137: 126136.

Gesteiro, E; Guijarro, L; Sánchez-Muniz, F J; VidalCarou, M D C; Troncoso, A; Venanci, L; Jimeno, V; Quilez, J; Anadón, A and González-Gross, M (2019). Palm oil on the edge. Nutrients, 11(9): 2008. DOI: $10.3390 /$ nu11092008.

Global Market Insight (2020). Fatty methyl ester sulphonate market size, industry analysis report, regional outlook, application development potential, price trends, competitive market share \& forecast, 2019-2025. https: / / www.gminsights.com/ industry-analysis / fatty-methyl-ester-sulphonatemarket, accessed on 17 February 2020.

Goh, K M; Wong, Y H; Abas, F; Lai, O M; Cheong, L Z; Wang, Y; Wang, Y and Tan, C P (2019). Effects of shortening and baking temperature on quality, MCPD ester and glycidyl ester content of conventional baked cake. LWT, 116: 108553. DOI: 10.1016/j.lwt.2019.108553.

Guedes, RDS; DaSilva, T L; Luis, Z G and ScherwinskiPereira, J E (2011). Initial requirements for embryogenic calluses initiation in thin cell layers explants from immature female oil palm inflorescences. African J. Biotechnology, 10: 10774-10780.

Gupta, S V; Khosla, P; Ji, X; Sambanthamurthi, R and Tan, Y A (2019). Anti-proliferative effects of palm vegetation liquor and extracts thereof in preventing pancreatic cancer. US patent No.10342844B2.

Habi Mat Dian, N L; Ying, W S; Yen, F J; Meganathan, P; Nik Ibrahim, N M A; Mohd Hassim, N A; Wasoh, $\mathrm{H}$ and Ming, L O (2019a). Palm-based vitamin E (tocotrienol-rich fraction) has excellent stability in chewable tablet after one-year of storage at ambient temperature. J. Oil Palm Res. Vol. 31(4): 662-669.

Habi Mat Dian, N L; Ying, L Y; Ibrahim, N M A N; Hassim, N A M; Huey, S M; Ping, T C and Ming, L O (2019b). Low-temperature directed interesterification increases triunsaturated and trisaturated triacylglycerols of palm oil and affects its thermal, polymorphic and microstructural properties. J. Oil Palm Res. Vol. 31(1): 95-109.

Halim, N; Kuntom, A; Shinde, R and Banerjee, K (2019). Determination of paraquat residues in palm oil by high performance liquid chromatography with UV and tandem mass spectrometry. European J. Lipid Science and Technology, 121: 1900092. DOI:10.1002/ ejlt.201900092.

Hamid, M H A; Sahidan, A S and Moslim, R (2019). Impact of Economic Stimulus Package II Incentive Scheme (PRE2) on yield and income of oil palm smallholders in peninsular Malaysia. Oil Palm Industry Economic J. Vol. 19(1): 35-42.

Ho, C L; Tan, Y C; Yeoh, K A; Lee, W K; Ghazali, A K; Yee, W Y and Hoh, C C (2019). Leaf transcriptome of oil palm (Elaeis guineensis Jacq.) infected by Ganoderma boninense. Trees Genetics and Genomes, 9(2): 377-386.

Hoong, S S; Arniza, M Z; Mariam, N M D N S; Armylisas, A H N and Yeong, S K (2019). Synthesis and physicochemical properties of novel lauric acid capped estolide esters and amides made from oleic acid and their evaluations for biolubricant basestock. Industrial Crops and Products, 140: 111653. DOI: $10.1016 /$ j.indcrop.2019.111653.

Hutabarat, S; Slingerland, $M$ and Dries L (2019). Explaining the 'Certification Gap' for different types of oil palm smallholders in Riau Province, Indonesia. J. Environment \& Development, 28(3): 253-281.

Ibragimov, A; Sidique, S F and Tey, Y S (2019). Productivity for sustainable growth in Malaysian oil palm production: A system dynamics modeling approach. J. Cleaner Production, 213: 1051-1062.

Intasit, R; Cheirsilp, B; Louhasakul, Y; Boonsawang, P; Chaiprapat, S and Yeesang, J (2019). Valorization of palm biomass wastes for biodiesel feedstock and clean solid biofuel through non-sterile repeated solid-state fermentation. Bioresource Technology, 298: 122551. DOI: 10.1016/j.biortech.2019.122551.

Jacob, F; Cros, D; Cochard, B and DurandGasselin, T (2017). Agrigenomics in the breeder's toolbox: Latest advances towards an optimal 
implementation of genomic selection in oil palm. Proc. of the International Seminar on 100 Years of Technological Advancement in Oil Palm Breeding \& Seed Production. ISOPB Conference. KLCC, Kuala Lumpur. p. 21.

Jayanthi, M; Mohan, N M and Mandal, P K (2011). Direct somatic embryogenesis and plantlet regeneration in oil palm. J. Plant Biochemistry and Biotechnology, 20: 249-251. DOI: 10.1007/ s13562-0110053-6.

Jelani, A R; Azaman, M I H and Ahmad, M R (2019). The effect of vibration isolator on the magnitude of hand-arm vibration (HAV) of the oil palm motorised cutter (CANTAS). J. Oil Palm Res. Vol. 31(1): 86-94.

Kalyana Babu, B; Mary Rani, KL; Sarika, S; Mathur, R K; Naveen Kumar, P; Ravichandran, G; Anitha, P and Bhagya, H P (2019a). Development and validation of whole genome-wide and genic microsatellite markers in oil palm (Elaeis guineensis Jacq.): First microsatellite database (OpSatdb). Scientific Reports, 9:1899. DOI: 10.1038/s41598-018-37737-7.

Kalyana Babu, B; Mathur, R K; Ravichandran, G and Venu, M V B (2019b). Genome-wide association study (GWAS) for stem height increment in oil palm (Elaeis guineensis) germplasm using SNP markers. Tree Genetics \& Genomes, 15: 40. DOI:10.1007/s11295019-1349-2.

Kamarudin, N; Idris, A S and Mazmira, M M M (2019). Prospects in sustainable control of oil palm pests and diseases through the enhancement of ecosystem services - The way forward. J. Oil Palm Res. Vol. 31(3): 381-393.

Kamaruzaman, M R; Chin, S Y; Pui, E C L; Prasetiawan, H and Azizan, N (2019). Synthesis of biobased polyester polyol through esterification of sorbitol with azelaic acid catalyzed by tin (II) oxide: A kinetic modeling study. Industrial and Engineering Chemistry Research, 58: 510-516.

Kaufmann, K C; Favero, F D F; De Vasconcelos, M A M; Godoy, H T; Sampaio, K A and Barbin, D F (2019). Portable NIR spectrometer for prediction of palm oil acidity. J. Food Science, 84(3): 406-411.

Khasim, N and Omar, R Z R (2019). Integration of latex timber clone rubber affects the oil palm yield. $J$. Oil Palm Res. Vol. 31(2): 262-270.

Komariah, R N; Miyamoto, T; Tanaka, S; Prasetiyo, K W; Syamani, F A; Subyakto; Umezawa, T; Kanayama, $K$ and Umemura, K (2019). High-performance binderless particleboard from the inner part of oil palm trunk by addition of ammonium dihydrogen phosphate. Industrial Crops and Products, 141: 111761. DOI: 10.1016/j.indcrop.2019.111761.

Kong, S-H; Loh, S K; Bachmann, R T; Zainal, H and Cheong, K Y (2019). Palm kernel shell biochar production, characteristics and carbon sequestration potential. J. Oil Palm Res. Vol. 31(3): 508-520.

Kosheela, D P; Raghunanan, L; Bouzidi, L; Yeong, SK and Narine, SS (2019a). Lipid-derived monoamide as phase change energy storage materials. International J. Energy Research, 43(13): 6934-6950.

Kosheela, D P; Raghunanan, L; Bouzidi, L; Yeong, S K and Narine, S S (2019b). The anomalous behaviour of aliphatic fatty diamides: Chain length and hydrogen bonding interactions. Solar Energy Materials and Solar Cells. 201: 110056. DOI: 10.1016/j. solmat.2019.110056.

Kushairi, A; Tarmizi, A H; Zamzuri, I; Ong-Abdullah, M; Samsul Kamal, R; Ooi, S E and Rajanaidu, N (2010). Production, performance and advances in oil palm tissue culture. Proc. of the International Seminar on Advances in Oil Palm Tissue Culture. Yogyakarta, Indonesia. p. 1-23.

Kushairi, A; Meilina, O A; Balu, N; Elina, H; Mohd Noor, I Z B; Razmah, G; Vijaya, S; Sundram, S and Ahmad Parveez, G K (2019). Oil palm economic performance in Malaysia and R\&D progress in 2018. J. Oil Palm Res. Vol. 31(2): 165-194. DOI: https: / / doi. org/10.21894/jopr.2019.0026.

Kyriaki, E; Konstantinidou, C; Giama, E and Papadopoulos, A M (2018). Life cycle analysis (LCA) and life cycle cost analysis (LCCA) of phase change materials (PCM) for thermal applications: A review. International J. Energy Research, 42(9): 30683077.

Lam, W Y; Kulak, M; Sim, S; King, H; Huijbregts, M A J and Chaplin-Kramer, R (2019). Greenhouse gas footprints of palm oil production in Indonesia over space and time. Science of the Total Environment, 688: 827-837.

Lang, H L (2020). Can CPO prices remain at MYR3,000/tonne? Paper presented at the Review \& Outlook (R\&O) Seminar 2020. Kuala Lumpur, Malaysia.

Lau, S Y; Phuan, S L; Danquah, M K and Acquah, C (2019). Sustainable palm oil refining using pelletized and surface-modified oil palm boiler ash (OPBA) biosorbent. J. Cleaner Production, 230: 527-535.

Le, V T; Sarpan, N; Huynh, K; Ooi, S E; Napis, S; Ho, C L; Ong-Abdullah, M; Chin, C F and Namasivayam, P (2010). A novel transcript of oil palm (Elaeis guineensis 
Jacq.), Eg707, is specifically upregulated in tissues related to totipotency. Molecular Biotechnology, 48: 156-164. DOI: 10.1007/s12033-010-9356-4.

Leadbeater, N E and Stencel, L M (2006). Fast, easy preparation of biodiesel using microwave heating. Energy and Fuels, 20: 2281-2283.

Lee, L Y; Ahmed, O H and Jalloh, M B (2019). Brief review on climate change and tropical peatlands. Geoscience Frontiers, 10(2): 373-380.

Li, C; Cobb, L K; Vesper, H W and Asma, S (2019b). Global surveillance of trans-fatty acids. Preventing Chronic Disease, 16: 190121. DOI: 10.5888/ pcd16.190121.

Li, X; Wu, G; Yang, F; Meng, L; Huang, J; Zhang, H; Jin, $Q$ and Wang, $X$ (2019a). Influence of fried food and oil type on the distribution of polar compounds in discarded oil during restaurant deep frying. Food Chemistry, 272: 12-17.

Liu, C; Meng, Z; Chai, X; Liang, X; Piatko, M; Campbell, $S$ and Liu, Y (2019). Comparative analysis of graded blends of palm kernel oil, palm kernel stearin and palm stearin. Food Chemistry, 286: 636643.

Loh, S K; Nasrin, A B; Mohamad Azri, S; Bukhari, N A; Muzzammil, N and Stasha Eleanor, R A (2019a). Biogas capturing facilities in palm oil mills: Current status \& way forward. Palm Oil Engineering Bulletin No. 75: 27-36.

Loh, S K; Lai, M E and Ngatiman, M (2019b). Vegetative growth enhancement of organic fertilizer from anaerobically-treated palm oil mill effluent (POME) supplemented with chicken manure in food-energy-water nexus challenge. Food and Bioproducts Processing, 117: 95-104.

Luke, S H; Advento, A D; Aryawan, A A; Adhy, D N, Ashton-Butt, A; Barclay, H; Dewi, J P; Drewer, J; Dumbrell, A J; Edi, E and Eycott, A E (2019). Managing oil palm plantations more sustainably: Large-scale experiments within the Biodiversity and Ecosystem Function in Tropical Agriculture (BEFTA) Programme. Frontiers in Forests and Global Change, 2: 75. DOI: $10.3389 /$ ffgc.2019.00075.

Mahmood, H; Moniruzzaman, M; Iqbal, T; Yusup, S; Rashid, M and Raza, A (2019). Comparative effect of ionic liquids pretreatment on thermogravimetric kinetics of crude oil palm biomass for possible sustainable exploitation. J. Molecular Liquids, 282: 8896.

Maizatul, S M; Dickinson, $\mathrm{M}$ and Idris, A S (2019). Molecular characterization of Phytophthora palmivora responsible for bud rot disease of oil palm in Colombia. World J. Microbiology and Biotechnology, 35(3): 44. DOI: https: / / doi.org/10.1007/ s11274-0192618-9.

Maneechakr, P and Karnjanakom, S (2019). A combination of $2 \mathrm{k}$ factorial with Box-Behnken designs for FAME production via methanolysis of waste cooking palm oil over low-cost catalyst. J. Environmental Chemical Engineering, 7(5): 103389. DOI: $10.1016 /$ j.jece.2019.103389.

Manning, F C; Kho, L K; Hill, T C; Cornulier, T and Teh, Y A (2019). Carbon emulsions from oil palm plantations on peat soil. Frontiers in Forests and Global Change, 2: 37. DOI: 10.3389/ffgc.00037.

Matinja, A I; Mohd Zain, N A; Suhaimi, M S and Alhassan, A J (2019). Optimization of biodiesel production from palm oil mill effluent using lipase immobilized in PVA-alginate-sulfate beads. Renewable Energy, 135: 1178-1185.

McNutt, J and He, Q S (2016). Development of biolubricants from vegetable oils via chemical modification. J. Industrial and Engineering Chemistry, 36: $1-12$.

Meuwissen, T H E; Hayes, B J and Goddard, M E (2001). Prediction of total genetic value using genome-wide dense marker maps. Genetics, 157: 1819-1829.

Middelberg, J; Azhar, B; Khoon, K L and Van Der Meer, P J (2019). An ecosystem services analysis of oil palm and alternative land use systems on peat in Malaysia. J. Oil Palm Res. Vol. 31(3): 468-479.

Midot, F; Lau, S Y L; Wong, W C; Tung, H J; Yap, M L; Lo, M L; Jee, M S; Dom, S P and Melling, L (2019). Genetic diversity and demographic history of Ganoderma boninense in oil palm plantations of Sarawak, Malaysia inferred from ITS regions. Microorganisms, 7(10): 464. DOI: 10.3390/ microorganisms7100464.

Mirande-Ney, C; Tcherkez, G; Gilard, F; Ghashghaie, J and Lamade, E (2019). Effects of potassium fertilization on oil palm fruit metabolism and mesocarp lipid accumulation. J. Agricultural and Food Chemistry, 67(33): 9432-9440.

Mistry, D E (2019). Palm \& lauric oils price outlook 2020. Paper presented at the $15^{\text {th }}$ Indonesian Palm Oil Conference and 2020 Price Outlook. Bali, Indonesia.

Mohamed Azni, I N A; Sundram, S and Vasagi, R (2019). Pathogenicity of Malaysian Phytophthora 
palmivora on cocoa, durian, rubber and oil palm determines the threat of bud rot disease. Forest Pathology. DOI:10.1111/efp.12557.

Mohamed Halim, R and Abd Aziz, A (2019). MPOB commitment towards clean air regulatory compliance. Palm Oil Engineering Bulletin No. 130: 13-17.

MPOB (2020). Malaysian Oil Palm Statistics 2019. 39 Edition. MPOB, Bangi. 289 pp.

Munasinghe, M; Jayasinghe, P; Deraniyagala, Y; Matlaba, V J; Dos Santos, J F; Maneschy, M $C$ and Mota, J A (2019). Value-supply Chain Analysis (VSCA) of crude palm oil production in Brazil, focusing on economic, environmental and social sustainability. Sustainable Production and Consumption, 17: 161-175.

Muniroh, M S; Nusaibah, S A; Vadamalai, G and Siddique, Y (2019). Proficiency of biocontrol agents as plant growth promoters and hydrolytic enzyme producers in Ganoderma boninense infected oil palm seedlings. Current Plant Biology, 20: 100116. DOI: 10.1016/j.cpb.2019.100116.

Myint, K A; Mohd Din, A; Rafii, M Y; Mohd Yusoff, A S; Ramlee, S I; Zulkifli, Y and Oladosu, Y (2019). Genetic diversity and selection criteria of MPOBSenegal oil palm (Elaeis guineensis Jacq.) germplasm by quantitative traits. Industrial Crops and Products, 139: 111558. DOI: 10.1016/j.indcrop.2019.111558.

Nasrin, A B; Loh, S K; Sukiran, M A; Bukhari, N A and Abdul Aziz, A (2019). Technical assessment and flue gases emission monitoring of an oil palm biomass - biogas cofired boiler. Environmental Progress and Sustainable Energy. DOI: 10.1002/ ep.13189.

Ng, K H; Cheng, Y W; Lee, Z S and Cheng, C K (2019). A study into syngas production from catalytic steam reforming of palm oil mill effluent (POME): A new treatment approach. International J. Hydrogen Energy, 44(37): 20900-20913.

Ng, N H and Yung, C L (2019). Nuclear magnetic resonance spectroscopic characterisation of palm biodiesel and its blends. Fuel. DOI: 10.1016/j. fuel.2019.116008.

Ngando-Ebongue, G F; Ajambang, W N; Koona, P and Firman, B I (2012). Oil palm. Technological Innovations in Major World Oil Crops (Gupta, S K ed.). Volume I. Springer, London. p. 165-200.

Noor Azeerah, A; Rozita, Y; Mohamed, K A; Haliza, A A and Zainab, I (2019). Production of palm-based glycol ester over solid catalysed esterification of lauric acid via microwave heating. Chemical Engineering J., 382: 122975.

Norhayati, M N; Sendijarevic, A; Sendijarevic, V; Sendijarevic, I; Tuan Noor Maznee, T I; Mohd Noor, M A; Yeong, S K and Hazimah, A H (2016). Comparison of adipic versus renewable azelaic acid polyester polyols as building blocks in soft thermoplastic polyurethanes. J. Amer. Oil Chem. Soc., 93(11): 1529-1540.

Nursyairah, J; Lau, H L N; Daryl, J T; Yung, C L; Wan Hasamudin, W H; Ropandi, M; Yahaya, H; Noraida, O and Astimar, A A (2019). Mandatory use of B10 palm biodiesel in transportation sector by February 2019. Palm Oil Engineering Bulletin No. 130: 50-52.

Nyouma, A; Bell, J M; Jacob, F and Cros, D (2019). From mass selection to genomic selection: One century of breeding for quantitative yield components of oil palm (Elaeis guineensis Jacq.). Tree Genetics and Genomes, 15: 69. DOI: 10.1007/s11295019-1373-2.

Ochoa, J C; Herrera, M; Navia, M and Romero H M (2019). Visualization of Phytophthora palmivora infection in oil palm leaflets with fluorescent proteins and cell viability markers. Plant Pathology J., 35(1): 19-31. DOI: 10.5423/PPJ. OA.02.2018.0034.

Oey, S B; Van der Fels Klerx, H J; Fogliano, V and Van Leeuwen, S P (2019). Mitigation strategies for the reduction of 2 and 3 MCPD esters and glycidyl esters in the vegetable oil processing industry. Comprehensive Reviews in Food Science and Food Safety, 18(2): 349-361.

Ong-Abdullah, M; Ordway, J M; Jiang, N; Ooi, S E; Azizah, M; Kok, S Y; Sarpan, N; Azimi, N; Tarmizi, A H; Zamzuri, I; Samsul Kamal, R; Nookiah, R; Singh, R; Low, L E T; Sachdeva, M; Smith, S W; Lakey, N; Martienssen, R A and Sambanthamurthi, R (2016). Tissue culture and epigenetics. The Planter, 92(1087): 741-749.

Ooi, S E; Choo, C N; Zamzuri, I and Ong-Abdullah, M (2012). A candidate auxin-responsive expression marker gene, EgIAA9, for somatic embryogenesis in oil palm (Elaeis guineensis Jacq.). Plant Cell Tissue and Organ Culture, 110: 201-212.

Ooi, S E; Sarpan, N; Abdul Aziz, N; Azimi, N and Ong-Abdullah, M (2019). Differential expression of heat shock and floral regulatory genes in pseudocarpel initials of mantled female inflorescences from Elaeis guineensis Jacq. Plant Reproduction, 32: 167-179. DOI: 10.1007/s00497-0180350-5. 
Osorio-Guarín, J A; Garzón-Martínez, G A; Delgadillo-Duran, P; Bastidas, S; Moreno, L P; Enciso-Rodríguez, F E; Cornejo, O E and Barrero, L S (2019). Genome-wide association study (GWAS) for morphological and yield-related traits in an oil palm hybrid (Elaeis oleifera x Elaeis guineensis) population. BMC Plant Biology, 19: 533. DOI: 10.1186/s12870019-2153-8.

Pang, M; Ge, Y; Cao, L; Cheng, J and Jiang, S (2019). Physicochemical properties, crystallization behavior and oxidative stabilities of enzymatic interesterified fats of beef tallow, palm stearin and camellia oil blends. J. Oleo Science, 68(2): 131-139.

Parveez, G K A; Khoon, K L; Hill, T C; Arn, T Y and Kushairi, A (2019). Sustainable oil palm cultivation in Malaysia - Are peatlands a suitable choice? J. Oil Palm, Environment and Health (JOPEH), 10: 13-18.

Peng, T S; Hashim, K; Mansor, N H; Kannan, P; Ariffin, A; Johari, M A and Isnin, K A (2019). Assessment on knowledge on fertiliser management among independent smallholders in Malaysia. Oil Palm Industry Economic J., 19(2): 1-16.

Purnomo, H; Okarda, B; Dermawan, A; Ilham, Q P; Pacheco, P; Nurfatriani, F and Suhendang, E (2020). Reconciling oil palm economic development and environmental conservation in Indonesia: A value chain dynamic approach. Forest Policy and Economics Vol. 111: 102089. DOI: https://doi.org/10.1016/j. forpol.2020.102089.

Rahmahwati, R; Zulkilfli, A M and Ramle, M (2019). Factors affecting yield achieved by participants of the quality oil palm seedlings assistance scheme in Sabah and Sarawak. Oil Palm Industry Economic J. Vol. 19(2): 44-56.

Rahman, N; Bruun, T B; Giller, K E; Magid, J; Van De Ven, G W and De Neergaard, A (2019). Soil greenhouse gas emissions from inorganic fertilizers and recycled oil palm waste products from Indonesian oil palm plantations. Gcb Bioenergy, 11(9): 1056-1074.

Rakib, M R M; Bong, C F J; Khairulmazmi, A; Idris, A S; Jalloh, M B and Wahida, N H (2017). Ganoderma species of basal and upper stem rots in oil palm (Elaeis guineensis) in Sarawak, Malaysia. J. Academia UiTM Negeri Sembilan, 5: 27-35.

Ramle, N A; Jawaid, M; Zainudin, E S and Yamani, S A K (2019). Tensile, physical and morphological properties of oil palm empty fruit bunch/sugarcane bagasse fibre reinforced phenolic hybrid composites. J. Materials Research and Technology, 8(4): 3466-3474.
Research and Markets (2020). Global oleochemical market - Industry trends, opportunities and forecasts to 2023. https://www.researchandmarkets.com/ reports / 4451968 / global-oleochemical-marketindustry-trends, accessed on 17 February 2020.

Ribeiro, D G; De Almeida, R F; Fontes, W; De Souza Castro, M; Valle De Sousa, M; Ricart, C A O; Da Cunha, R N V; Lopes, R; Scherwinski-Pereira, J E and Mehta, A (2019). Stress and cell cycle regulation during somatic embryogenesis plays a key role in oil palm callus development. J. Proteomics, 192: 137146.

Rubinsin, N J; Wan Daud, W R; Kamarudin, S K; Masdar, M S; Rosli, M I; Samsatli, S; Tapia, J F; Wan Ab Karim Ghani, W A and Lim, K L (2020). Optimization of oil palm empty fruit bunches value chain in Peninsular Malaysia. Food and Bioproducts Processing, 119: 179-194.

Rulli, M C; Casirati, S; Dell'Angelo, J; Davis, K F; Passera, C and D'Odorico, P (2019). Interdependencies and telecoupling of oil palm expansion at the expense of Indonesian rainforest. Renewable and Sustainable Energy Reviews, 105: 499-512.

Ruslan, S A; Muharam, F M; Zulkafli, Z; Omar, D; and Zambri, M P (2019). Using satellite-measured relative humidity for prediction of Metisa plana's population in oil palm plantations: A comparative assessment of regression and artificial neural network models. PLoS ONE, 14(10): e00223968.

Sahidan, A S; Rahman, A R A and Moslim, R (2019). The impact of social network towards oil palm independent smallholders. Oil Palm Industry Economic J. Vol. 19(1): 9-16.

Said, N; Dzolkhifli, O; Abbas, N and Mui-Yun, W (2019). Pyraclostrobin suppressed Ganoderma basal stem rot (BSR), promoted plant growth and induced early expression of $\beta$-1,3-glucanase in oil palm (Elaeis guineensis). J. Oil Palm Res. Vol. 31 (2): 248-261. DOI: 10.21894/jopr.2019.0021.

Sambanthamurthi, R; Ai, T Y; Koledova, V V; Weinberg, R P; Rha, C K and Sinskey, A J (2019). Oil palm phenolics composition for the protection of humans, organs, cells and tissues against the injurious effects of exposure to ionizing radiation. US patent application 16/067, 130.

Schoneveld, G C; Ekowati, D; Andrianto, A and Van Der Haar, S (2019). Modeling peat- and forestland conversion by oil palm smallholders in Indonesian Borneo. Environmental Research Letters, 14(1): 119501. DOI: 10.1088 / 1748-9326/ab4870. 
Senawi, R; Rahman, N K; Mansor, N and Kuntom, A (2019). Transformation of oil palm independent smallholders through malaysian sustainable palm oil. J. Oil Palm Res. Vol. 31(3): 496-507.

Severo, I A; Siqueira, S F; Deprá, M C; Maroneze, M M; Zepka, L Q and Jacob-Lopes, E (2019). Biodiesel facilities: What can we address to make biorefineries commercially competitive? Renewable and Sustainable Energy Reviews, 112: 686-705.

Shevade, V S and Loboda, T V (2019). Oil palm plantations in Peninsular Malaysia: Determinants and constraints on expansion. PLOS ONE 14(2): e0210628. DOI: 10.1371/journal.pone.0210628.

Shah, F and Wu, W (2019). Soil and crop management strategies to ensure higher crop productivity within sustainable environments. Sustainability, 11(5): 1485. DOI: 10.3390 / su11051485.

Shamsilawani A B; Mohd Shawal, T M and Mohd Mazmira, M M (2019). Soil bacteria biodiversity in development of secondary logged-over forest to oil palm plantation in mineral soil of Belaga, Sarawak. J. Oil Palm Res. Vol. 31(3): 394-411.

Silva, W C; Santiago, J K; Capristo, M F; Ferrari, R A; Vicente, E; Sampaio, K A and Arisseto, A P (2019). Washing bleached palm oil to reduce monochloropropanediols and glycidyl esters. Food Additives E Contaminants: Part A, 36(2): 244-253.

Subramaniam, V; Kuntom, A; Zainal, H; Loh, S K; Abdul Aziz, A and Ahmad Parveez, G K (2019a). Analysis of the uncertainties of the inclusion of indirect land use change into the European Union Renewable Energy Sources Directive II. J. Oil Palm Res. Vol. 31(3): 480-488.

Subramaniam, S; Selvaduray, KR and Radhakrishnan, A K (2019b). Bioactive compounds: Natural defense against cancer? Biomolecules, 9(12): 758.

Sumaiyah, M N M; Ismail, A R; Zafarizal, A A H and Zainab, I (2019). Influence of surfactant structure in physical stability and physiochemical properties of insecticide emulsions. J. Oil Palm Res. Vol. 31(4): 670-680.

Sundram, S; Angel, L P L and Sirajuddin, S A (2019). Integrated balanced fertiliser management in soil health rejuvenation for a sustainable oil palm cultivation: A review. J. Oil Palm Res. Vol. 31(3): 348363. DOI: 10.21894/jopr.2019.0045.

Syarifah-Noratiqah, S B; Zulfarina, M S; Ahmad, S.U; Fairus, S and Naina-Mohamed, I (2019). The pharmacological potential of oil palm phenolics
(OPP) individual components. International J. Medical Sciences, 16(5): 711-719.

Syariyanto, N; Widyastuti, U and Mathius, N $\mathrm{T}$ (2018). Gene expression analysis of somatic embryogenesis in oil palm. International J. Oil Palm, 1: 38-49. http://www.ijop.id/index.php/ ijop/article/view / 5 .

Tan, Y D and Lim, J S (2019). Feasibility of palm oil mill effluent elimination towards sustainable Malaysian palm oil industry. Renewable and Sustainable Energy Reviews, 111: 507-522.

Tay, K Y; Asnuzilawati, A; Samsuri, A; Marzuki, Ismail and Wahizatul, A A (2019). The dataset for antifeedant activity of eugenol derived compounds against red palm weevil (Rhynchophorus ferrugineus, Olivier) larvae. Data in Brief, 25: 104227.

Teh, S-S; Loh, S-K and Mah, S-H (2019). Development of choline-based deep eutectic solvents for efficient concentrating of hemicelluloses in oil palm empty fruit bunches. Korean J. Chemical Engineering, 36(10): 1619-1625.

Tham, S Y; Loh, H S; Mai, C W and Fu, J Y (2019). Tocotrienols modulate a life or death decision in cancers. International J. Molecular Sciences, 20(2): 372. DOI: 10.3390 /ijms20020372.

Tiong, Y W; Yap, C Y; Gan, S and Yap, W S P (2019). Optimisation studies on the conversion of oil palm biomass to levulinic acid and ethyl levulinate via indium trichloride-ionic liquids: A response surface methodology approach. Industrial Crops and Products, 128: 221-234.

Tohiran, K A; Nobilly, F; Maxwell, T; Puan, C L; Zakaria, M; Zulkifli, R; Ashton-Butt, A and Azhar, B (2019a). Cattle grazing benefits farmland bird community composition in oil palm plantations. Ornithological Science, 18(1): 81-94.

Tohiran, K A; Nobilly, F; Zulkifli, R; AshtonButt, A and Azhar, B (2019b). Cattle-grazing in oil palm plantations sustainably controls understory vegetation. Agriculture, Ecosystems and Environment, 278: 54-60.

Truckell, I G; Shah, S H; Baillie, I C; Hallett, S $H$ and Sakrabani, R (2019). Soil and transport factors in potential distribution systems for biofertilisers derived from palm oil mill residues in Malaysia. Computers and Electronics in Agriculture, 166: 105005.

Tsouko, E; Alexandri, M; Fernandes, K V; Guimarães Freire, D M; Mallouchos, A and Koutinas, A A 
(2019). Extraction of phenolic compounds from palm oil processing residues and their application as antioxidants. Food Technology and Biotechnology, 57(1): 29-38.

Tuan Noor Maznee, T I; Nor, A I; Vahid, S; Ibrahim, S; Christi, M S; Hoong, S S; Mohd, A M N; Kosheela, D P P; Yeong, S K; Zainab, I; Emilia, A M; Norhazlin, $Z$ and Aisa, S (2019). Thermal and mechanical properties of thermoplastic urethanes made from crystalline and amorphous azelate polyols. J. Applied Polymer Science. DOI: 10.1002 / app.47890.

Vidya, A S (2015). Advance esterification reaction under microwaves. International J. Scientific and Research Publications, 5(1): 1-9.

Voon, P T; Lee, S T; Ng, T K W; Ng, Y T; Yong, X S; Lee, V K M and Ong, A S H (2019). Intake of palm olein and lipid status in healthy adults: A metaanalysis. Advances in Nutrition, 10(4): 647-659.

Wang, Y; Htwe, Y M; Li, J; Shi, P; Zhang, D; Zhao, $\mathrm{Z}$ and Ihase, $\mathrm{L} \mathrm{O}$ (2019). Integrative omics analysis on phytohormones involved in oil palm seed germination. BMC Plant Biology, 19: 363. DOI: 10.1186/s12870-019-1970-0.

Weckx, S; Inez, D and Marlene, L (2019). Tissue culture of oil palm: Finding the balance between mass propagation and somaclonal variation. Frontiers in Plant Science, 10: 722. DOI: 10.3389/ fpls.2019.00722.

Willett, W; Rockström, J; Loken, B; Springmann, M; Lang, T; Vermeulen, S; Garnett, T; Tilman, D; DeClerck, F; Wood, A and Jonell, M (2019). Food in the anthropocene: the EAT-Lancet Commission on healthy diets from sustainable food systems. The Lancet, 393(10170): 447-492.

Wong, Y H; Goh, K M; Nyam, K L; Nehdi, I A; Sbihi, H M and Tan, C P (2019a). Effects of natural and synthetic antioxidants on changes in 3-MCPD esters and glycidyl ester in palm olein during deep-fat frying. Food Control, 96: 488-493.

Wong, Y H; Goh, K M; Abas, F; Maulidiani, M; Nyam, K L; Nehdi, I A; Sbihi, H M Gewik, M M and Tan, C P (2019b). Rapid quantification of 3-monochloropropane-1, 2-diol in deep-fat frying using palm olein: Using ATR-FTIR and chemometrics. LWT, 100: 404-408.

World Economic Forum (2018). Innovation with a purpose: The role of technology innovation in accelerating food systems transformation, accessed on 17 February 2020.
Xia, W; Luo, T; Zhang, W; Mason, A S; Huang, D; Huang, X; Tang, W; Dou, Y; Zhang, C and Xiao, Y (2019a). Development of high-density SNP markers and their application in evaluating genetic diversity and population structure in Elaeis guineensis. Frontiers in Plant Science, 10: 130. DOI: 10.3389/ fpls.2019.00130.

Xia, W; Luo, T; Dou, Y; Zhang, W; Mason, AS; Huang, D; Huang, X; Tang, W; Wang, J; Zhang, C and Xiao, $Y(2019 b)$. Identification and validation of candidate genes involved in fatty acid content in oil palm by genome-wide association analysis. Frontiers in Plant Science, 10: 1263. DOI: 10.3389/ fpls.2019.01263.

Xia, Q; Akanbi, T O; Li, R; Wang, B; Yang, W and Barrow, C J (2019c). Lipase-catalysed synthesis of palm oil-omega-3 structured lipids. Food and Function, 10(6): 3142-3149.

Yee, T and Tiu, T K (2019). Effects of oxidised oils on inflammation-related cancer risk. J. Oil Palm Res. Vol. 31(1): 1-13.

Zahraee, S M; Golroudbary, S R; Shiwakoti, N; Kraslawski, A and Stasinopoulos, P (2019). An investigation of the environmental sustainability of palm biomass supply chains via dynamic simulation modeling: A case of Malaysia. J. Cleaner Production, 237: 117740 .

Zaied, B K; Nasrullah, M; Islam Siddique, M N; Zularisam, A W; Singh, L and Krishnan, S (2019). Enhanced bioenergy production from palm oil mill effluent by co-digestion in solar assisted bioreactor: Effects of hydrogen peroxide pretreatment. J. Environmental Chemical Engineering. DOI: 10.1016/j. jece.2019.103551.

Zainal, N A; Zulkifli, N W M; Gulzar, M and Masjuki, $\mathrm{H} \mathrm{H}$ (2018). A review on the chemistry, production, and technological potential of bio-based lubricants. Renewable and Sustainable Energy Reviews, 82(1): 80-102.

Zainal, Z; Abdul Rahim, A; Khaza'ai, H and Chang, S K (2019a). Effects of palm oil tocotrienolrich fraction (TRF) and carotenes in ovalbumin (OVA)-challenged asthmatic brown Norway rats. International J. Molecular Sciences, 20(7): 1764.

Zainal, Z; Rahim, A A; Radhakrishnan, A K; Chang, S K and Khaza'ai, H (2019b). Investigation of the curative effects of palm vitamin $\mathrm{E}$ tocotrienols on autoimmune arthritis disease in vivo. Scientific Reports, 9(1): 1-11.

Zaulkffali, A S; Razip, M; Najwa, N; Alwi, S; Sakinah, S; Abd Jalil, A; Mutalib, A; Sokhini, M; Gopalsamy, B; Chang, S K and Zainal, Z (2019). Vitamins D and E stimulate the PI3K-AKT signalling 
pathway in insulin-resistant SK-N-SH neuronal cells. Nutrients, 11(10): 2525.

Zayed, E M M; Zein El Din, A F M; Manaf, H H and Abdelbar, O H (2016). Floral reversion of mature inflorescence of date palm in vitro. Annals of Agricultural Science, 61: 125-133. DOI: 10.1016/j. aoas.2016.01.003.

Zhang, Z; Zhu, Z; Shen, B and Liu, L (2019). Insights into biochar and hydrochar production and applications: A review. Energy, 171: 581-598.
Zhou, J; Ma, Y; Jia, Y; Pang, M; Cheng, G and Cai, S (2019). Phenolic profiles, antioxidant activities and cytoprotective effects of different phenolic fractions from oil palm (Elaeis guineensis Jacq.) fruits treated by ultra-high pressure. Food Chemistry, 288: 68-77.

Zou, J; Zhang, Q; Zhu, Z; Gao, L; Zheng, Y and Li, D (2019). Embryogenic callus induction and fatty acid composition analysis of oil palm (Elaeis guineensis cv. Tenera). Scientia Horticulturae, 245: 125-130.

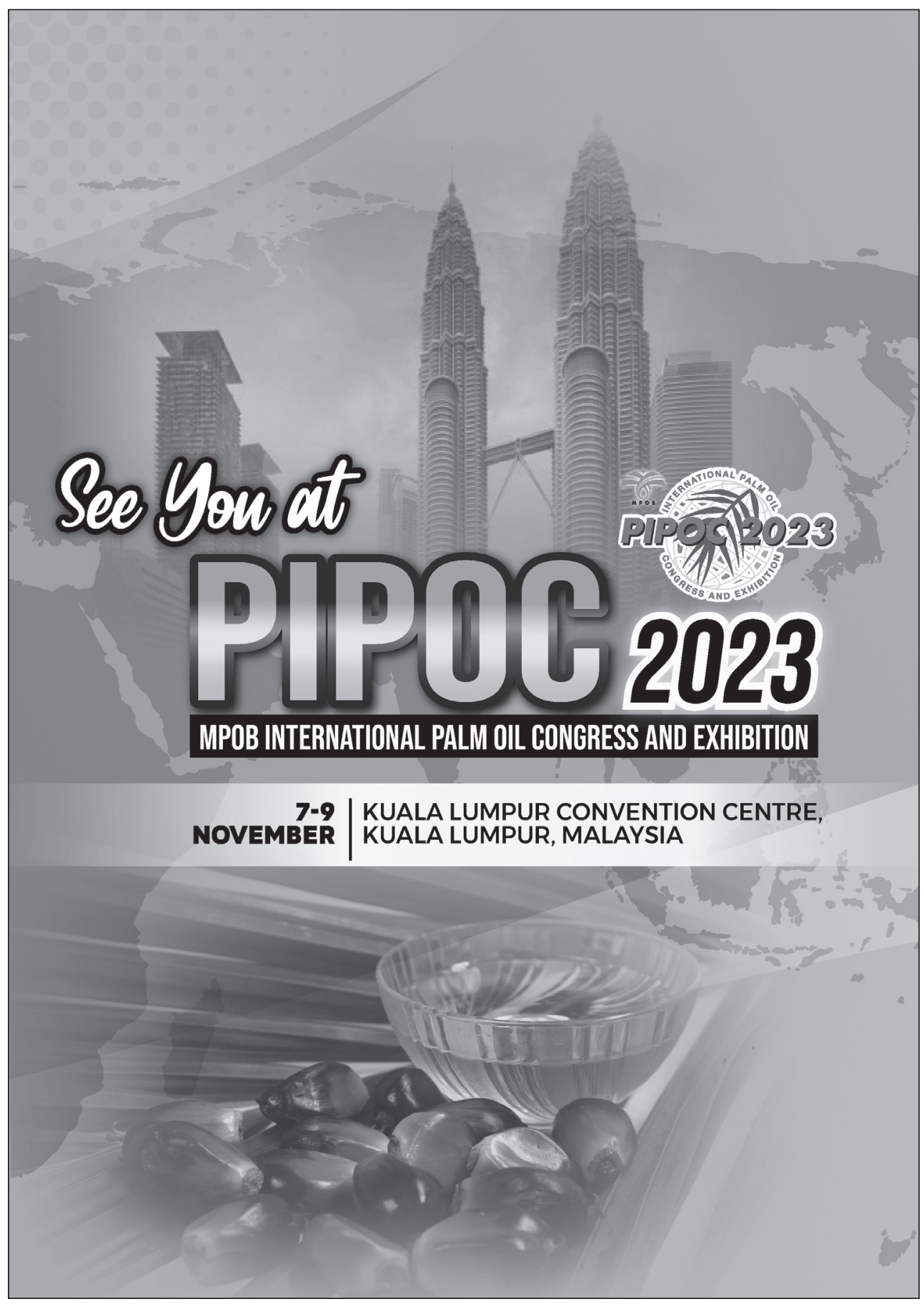

